\title{
Fermentation Processes Using Lactic Acid Bacteria Producing Bacteriocins for Preservation and Improving Functional Properties of Food Products
}

\author{
Grazina Juodeikiene1, Elena Bartkiene², Pranas Viskelis³, \\ Dalia Urbonaviciene ${ }^{3}$, Dalia Eidukonyte ${ }^{1}$ and Ceslovas Bobinas ${ }^{3}$ \\ ${ }^{1}$ Kaunas University of Technology, \\ ${ }^{2}$ Veterinary Academy, Lithuanian University of Health Sciences, \\ Institute of Horticulture, Lithuanian Research Centre for Agriculture and Forestry, \\ Lithuania
}

\section{Introduction}

During the recent years health-conscious consumers are looking for natural foods without chemical preservatives that will fit in their healthy lifestyle. The increasing consumption of precooked food, prone to temperature abuse, and the import of raw foods from developing countries are among the main causes of this situation. Biopreservation refers to extended shelf life and enhanced safety of foods using microorganisms and/or their metabolites (Ross et al., 2002). LAB is generally employed because they significantly contribute to the flavor, texture and, in many cases, to the nutritional value of the food products (McKay and Baldwin, 1990). LAB are used as natural or selected starters in food fermentations and exert the antimicrobial effect as a result of different metabolic processes (lactose metabolism, proteolytic enzymes, citrate uptake, bacteriophage resistance, bacteriocin production, polysaccharide biosynthesis, metal-ion resistance and antibiotic resistance) (Zotta, T., 2009; Corsetti, 2004). Lactic acid bacteria (LAB) play a key role in food fermentations where they not only contribute to the development of the desired sensory properties in the final product but also to their microbiological safety. LAB has a GRAS status (generally recognized as safe) and it has been estimated that $25 \%$ of the European diet and $60 \%$ of the diet in many developing countries consists of fermented foods (Stiles, 1996). Fermentation is one of the most ancient and most important food processing technologies. Fermentation is a relatively efficient, low energy preservation process, which increases the shelf life and decreases the need for refrigeration or other forms of food preservation technology. Currently, fermented foods are increasing in popularity (60\% of the diet in industrialized countries) and, to assure the homogeneity, quality, and safety of products, they are produced by the intentional application in raw foods in different microbial systems (starter/protective cultures) (Holzapfel et al., 1995).

Examples of vegetable lactic acid fermentations are: sauerkraut, cucumber pickles, and olives in the Western world; Egyptian pickled vegetables in the Middle East; Indian pickled 
vegetables and Korean kim-chi, Thai pak-sian-don, Chinese hum-choy, Malaysian pickled vegetables and Malaysian tempoyak. Lactic acid fermented cereals and tubers (cassava) include: Mexican pozol, Ghanaian kenkey, Nigerian gari; boiled rice/raw shrimp/raw fish mixtures: Philippine balao-balao, burong dalag; lactic fermented/leavened breads: sourdough breads in the Western world; Indian idli, dhokla, khaman, Sri-lankan hoppers; Ethiopian enjera, Sudanese kisra and Philippine puto; Lactic acid fermented cheeses in the Western world and Chinese sufu/tofu-ru. Lactic acid fermented yogurt/wheat mixtures: Egyptian kishk, Greek trahanas, Turkish tarhanas.

Moreover, because of the improved organoleptic qualities of traditional fermented food, extensive research on its microbial biodiversity has been carried out with the goal of reproducing these qualities, which are attributed to native microbiota, in a controlled environment.

Recent years the interest increased in bacteriocin-like inhibitory substances (BLIS) producing $\mathrm{LAB}$ because of their potential use as natural antimicrobial agents to enhance the safety of food products. Bacteriocins from LAB are described as "natural" inhibitors, in regard to LAB having a GRAS status. Bacteriocin-like inhibitory substances (BLIS) from LAB are antimicrobial compounds that possess bacteriocin requisites but that have not yeen characterized for their amino acid sequence (Jack et al., 1995). Bacteriocins from the generally recognized as safe $\mathrm{LAB}$, have received significant attention as a novel approach to the control of pathogens in foods (Klaenhammer, 1993; Settani et al., 2005). Nisin is the first antimicrobial polypeptide found in LAB (Rogers, 1928); at the time of discovery, the producer strains were identified as Streptococcus lactis [later classified as Lactococcus lactis] (Schleifer et al., 1985). Today nisin is a permitted preservative in at least 48 countries, in which it is used in a variety of products, including cheese, canned food and cured meat (Delves-Broughton, 1990). Another commercially produced bacteriocin is pediocin PA-1 produced by Pediococcus acidilactici and marketed as ATTA TM 2431 (Kerry Bioscience, Carrigaline, Co, Cork, Ireland). The source of natural or controlled microbiota and/or antimicrobial compounds could be traditional fermented foods. The health benefits attributed to peptides in these traditional products have, so far, not been established, however. Several factors can affect the bacteriocin activity including interaction with other bacteriocins, constituents from the cells as well as the growth medium, purity and concentration of exogenous added enzymes (Moreno et al., 2000). Enzymes present during food making originate from different sources: there are those that already exist in the plant raw material, those associated with the metabolic activity of yeasts or LAB, and those intentionally added to the formulations. For example, amylases are added for the intensification of the saccharification stage (Stauffer, 1994), while microbial lipases induce changes in lipid and short-chain fatty acid compositions (Martınez-Anaya, 1996). Up to date, numerous recent review articles focused on the isolation of novel LAB bacteriocin-like inhibitory substances produced by LAB, evaluation their inhibitory activities, classification, biochemical and genetic characterization, studying the sensitivity of the BLIS antimicrobial activity to different factors, e.g. enzymes in fermentation media and the mode of action of LAB bacteriocins, as well as on some of their food application (mainly animal origin) have been published. Unfortunately literature lacks of concentrated articles dealing with the use of bacteriocins or bacteriocin-producing strains for the biopreservation and improving functional properties of vegetable and fruit products. 


\section{Characterization of bacteriocins produced by lactic acid bacteria}

The antimicrobial ribosomal synthesized peptides produced by bacteria, including members of the LAB, are called bacteriocins. Such peptides are produced by many, if not all, bacterial species and kill closely related microorganisms (Jack et al., 1995). Due to their nature, they are inactivated by proteases in the gastrointestinal tract. Most of the LAB bacteriocins identified so far are thermo stable cationic molecules that have up to 60 amino acid residues and hydrophobic patches. Electrostatic interactions with negatively charged phosphate groups on target cell membranes are thought to contribute to the initial binding, forming pores and killing the cells after causing lethal damage and autolysin activation to digest the cellular wall (Gálvez et al., 1990). Example of damage caused by bacteriocin on $L$. monocytogenes CECT 4032 cells is presented in Figure 1.

The LAB bacteriocins have many attractive characteristics that make them suitable candidates for use as food preservatives, such as:

- Protein nature, inactivation by proteolytic enzymes of gastrointestinal tract

- Non-toxic to laboratory animals tested and generally non-immunogenic

- Inactive against eukaryotic cells

- Generally thermo resistant (can maintain antimicrobial activity after pasteurization and sterilization)

- Broad bactericidal activity affecting most of the Gram-positive bacteria and some, damaged, Gram-negative bacteria including various pathogens such as $L$. monocytogenes, Bacillus cereus, S. aureus, and Salmonella

- Genetic determinants generally located in plasmid, which facilitates genetic manipulation to increase the variety of natural peptide analogues with desirable characteristics

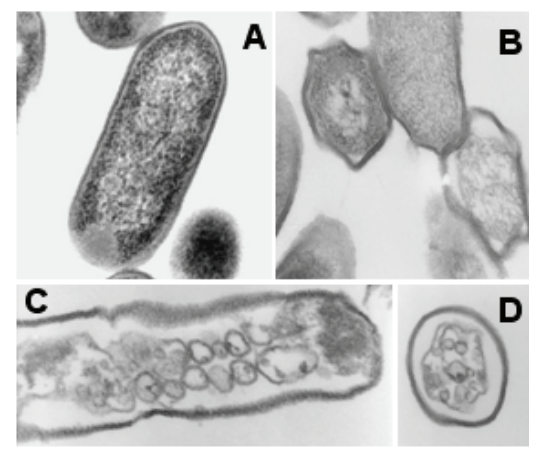

Fig. 1. Example of damage caused by bacteriocin on L. monocytogenes CECT 4032 cells. (A) cells without enterocin AS-48; (B) cells treated with $0.1 \mu \mathrm{g} / \mathrm{ml}$ of AS-48 for $2 \mathrm{~h}$; (C and D) cells treated with $3 \mu \mathrm{g} / \mathrm{ml}$ of enterocin AS-48 for 10 min (adapted from Mendoza et al., 1999).

For these reasons, the use of bacteriocins has, in recent years, attracted considerable interest for use as biopreservatives in food, which has led to the discovery of an ever-increasing potential of these peptides. Undoubtedly, the most extensively studied bacteriocin is nisin, which has gained widespread applications in the food industry. This FDA approved 
bacteriocin is produced by the GRAS microorganism Lactococcus lactis and is used as a food additive in at least 48 countries, particularly in processed cheese, dairy products and canned foods. Nisin is effective against food-borne pathogens such as L. monocytogenes and many other Gram-positive spoilage microorganisms (Thomas et al., 2000; Thomas and DelvesBroughton, 2001). Nisin is listed as E-234, and may also be cited as nisin preservative or natural preservative. In addition to the work on nisin, several authors have outlined issues involved in the approval of new bacteriocins for food use (Harlander, 1993).

\subsection{The biosynthetic pathway of bacteriocins}

The biosynthetic pathways of bacteriocins with the focus on class II bacteriocins (mainly produced by LAB from fermented plant products) will be discussed in this section. All bacteriocins are synthesized as a biologically inactive prepeptide carrying an $\mathrm{N}$-terminal leader peptide attached to the C-terminal propeptide (Hoover and Chen, 2005).

The mode of action of lactic acid bacteria bacteriocins belonging to class I, II and III are presented in Figure 2.

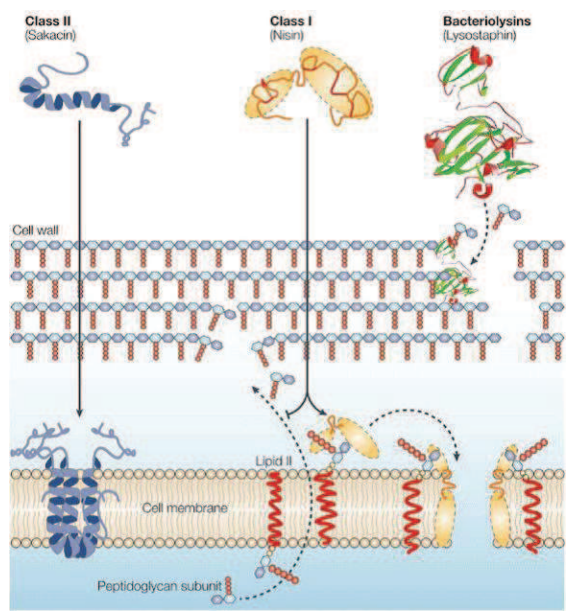

Fig. 2. Mode of action of bacteriocins by lactic acid bacteria.

Some bacteriocins (or lantibiotics) of class I (e.g. nisin) have a dual mode of action: (1) they prevent correct cell wall synthesis that leads to cell death by binding to lipid II - the main transporter of peptidoglycan subunits from the cytoplasm to the cell wall and (2) they employ lipid II as a docking molecule to initiate a process of membrane insertion and pore formation leading to a rapid cell death (Gillor et al., 2008; Cotter et al., 2005; Wiedemann et al., 2001). The majority of class II bacteriocins kill by inducing membrane permeabilization and the subsequent leakage of molecules from target bacteria (Gillor et al., 2008). Bacteriolysins (bacteriolytic proteins belonging to class III) function directly on the cell wall of Gram-positive targets leading to death and lysis of the target cell (Cotter et al., 2005).

Class II bacteriocins are synthesized as a prepeptide containing a conserved N-terminal leader and a characteristic double-glycine proteolytic processing site, and in contrast to lantibiotics, they do not undergo extensive posttranslational modification (Hoover and 
Chen, 2005). The examples of the class II bacteriocins are Sakacin P, G, A and Pediocin $\mathrm{PA}-1 / \mathrm{AcH}$.

A general scheme of the biosynthetic pathway of class II bacteriocins is shown in Figure 3 .

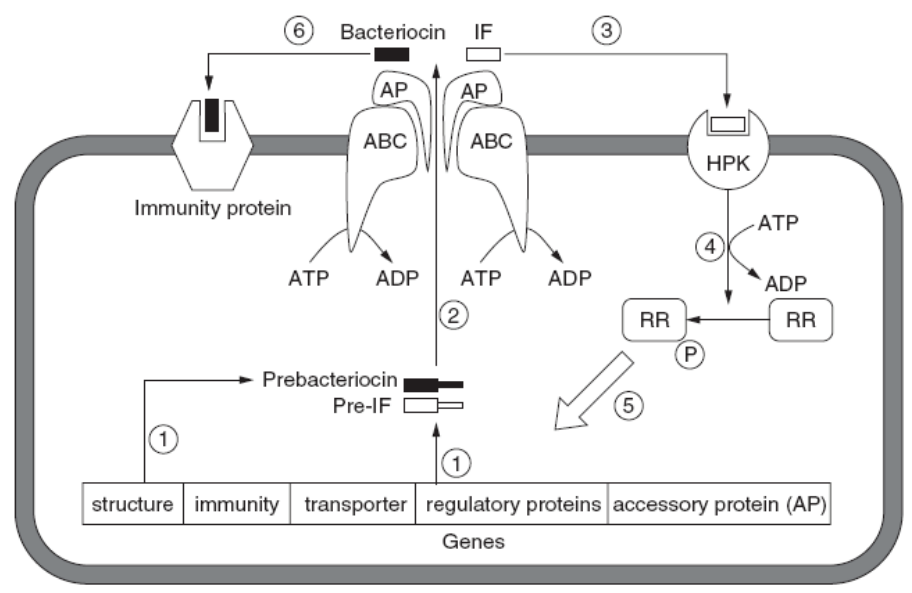

Fig. 3. The biosynthesis of class II bacteriocins. 1. Formation of prebacteriocin and prepeptide of induction factor (IF). 2. The processing of the prebacteriocin and pre-IF, and translocation by the ABC-transporter, resulting in the release of mature bacteriocin and IF. 3 . Histidine protein kinase (HPK) senses the presence of IF and autophosphorylates. 4 . The transfer of the phosphoryl group $(\mathrm{P})$ to the response regulator (RR). 5. The activation of the regulated genes transcription by the RR. 6. Producer immunity.

The production of most class IIa bacteriocins is regulated by a three-component system which includes a histidine protein kinase, a response regulator, and an induction factor. Some class IIa bacteriocins are autoregulated by a two-component signal transduction system, which is a well-known phenomenon in lantibiotics (Sahl et al., 1998). A threshold concentration of the bacteriocin, which functions as a signal molecule accumulating during growth, triggers the transcription of the genes coding for bacteriocin production, suggesting a self-inducing cell density (quorum-sensing)-regulated system (Sahl et al., 1998).

Class IIc bacteriocins are an exceptional case due to their production with a typical Nterminal signal sequence of the sec-type, processing and excretion through the general secretory pathway (Leer et al., 1995; Worobo et al., 1995). Once the prepeptide is formed, it is processed to remove the leader peptide concomitant with export from the cell through a dedicated ABC-transporter and its accessory protein (Nes et al., 1996).

\subsection{Activity spectra and biochemical properties of LAB and their produced bacteriocins}

As mentioned before, $\mathrm{LAB}$ bacteriocins tend to be active against a wide range of mostly closely related Gram-positive bacteria (Jack et al., 1995). Gänzle (1998) corroborated this while reviewing the inhibitory spectrum of bavaricin A, BLIS C57, and plantaricin ST31, produced by sourdough LAB, indicating no inhibition of Gram-negative bacteria, whereas a 
variety of Gram-positive bacteria were sensitive. The insensitivity of Gram-negative bacteria to bacteriocins from LAB strains might be explained by their outer membrane providing them with a permeability barrier (Messens et al., 2002). Furthermore, the producer strains are found to be immune towards their own bacteriocin (Gänzle, 1998). Studies on the resistance of List.monocytogenes strains towards bavaricin A confirmed that only 3 of the 245 strains examined were resistant to bavaricin A (Larsen and Nørrung, 2003), meanwhile Rasch and Knøchel (1998) reported about the correlation between bavaricin A sensitivity and pediocin PA-1 sensitivity of the strains.

The seldom inhibition of commonly encountered enteropathogenic bacteria (Enterobacter, Klebsiella, or Salmonella was announced as the weakness of the bacteriocins produced by Gram-positive bacteria. Gram-positive bacteriocins are restricted to kill other Grampositives and the killing range varies significantly (Gillor et al., 2008). Martínez-Cuesta et al. (2006) reported about the relatively narrow range of lactococcins $\mathrm{A}, \mathrm{B}$ and $\mathrm{M}$ able to inhibit only Lactococcus, meanwhile some type A lantibiotics (e.g. nisin A, mutacin B-Ny266) had a wide range while killing Actinomyces, Bacillus, Clostridium, Corynebacterium, Enterococcus, Gardnerella, Lactococcus, Listeria, Micrococcus, Mycobacterium, Propionibacterium, Streptococcus, and Staphylococcus as shown by Mota-Meira et al. (2005). These particular bacteriocins were found to be active against some medically important Gram-negative strains of Campylobacter, Haemophilus, Helicobacter, and Neisseria (Morency et al., 2001).

Furthermore, IIa class bacteriocins have relatively narrow killing spectrum as compared to I class bacteriocins and inhibit only closely related Gram-positive bacteria (Heng et al. 2007). However, pediocin was reported to have a fairly broad activity spectrum while inhibiting Streptococcus aureus and vegetative cells of Clostridium spp., Listeria and Bacillus spp. (Nes and Holo, 2000; Eijsink et al., 2002). Besides, maximum antimicrobial activity against Escherichia coli, Staphylococcus aureus and Bacillus cereus, though it was more effective against E. coli than others, showed bacteriocin produced by strain CA 44 of Lactobacillus genus isolated from carrot fermentation medium. This bacteriocin was stable at up to $100^{\circ} \mathrm{C}$ but its activity declined compared to that at $68^{\circ} \mathrm{C}$ and was completely lost at $121^{\circ} \mathrm{C}$. The maximum antimicrobial activity was retained within the $\mathrm{pH}$ range of $4-5$, but it was adversely affected by the addition of papain. Bacteriocin was also effective against $B$. cereus in different fruit products (pulp, juice and wine) indicating its potential application as a biopreservative in fruit products (Joshi et al., 2006).

Quite a few studies on a bacterocin activity possessed by L. sakei strains have been performed. Schillinger and Lücke (1989) reported about 221 surveyed lactobacilli strains, among those $19 \mathrm{~L}$. sakei strains, $3 \mathrm{~L}$. plantarum strains and $1 \mathrm{~L}$. curvatus strain were found to inhibit other lactobacilli. Bacteriocins were not identical according to the evaluation of supernatants antimicrobial spectra. Sakacin A produced by L. sakei Lb706 was reported to be active against List. monocytogenes strains 8732 and 17a, moreover 4 other strains of L. sakei and 1 strain of L. plantarum also shown antilisterial activity. Mørtvedt and Nes (1990) identified bacteriocin Lactosin S produced by L. sakei and described it as moderately heat stable, sensitive to protease and having antimicrobial activity against Lactobacillus, Pediococcus and Leuconostoc genera members. Furthermore, the instability of bacteriocin production and immunity was revealed by the plasmid biology investigation in L. sakei L45. Antagonistic effect of L. sakei CTC494 and sakacin K to different extents against List.innocua CTC1014 was demonstrated by Hugas and co-workers (1998). While Axelsson with co- 
workers (1988) developed a system for heterologous expression using a bacteriocin-negative L. sakei Lb790 strain, where into Lb790 introduced two plasmids allowed the production of various bacteriocins (sakacin $\mathrm{P}$, pediocin PA-1, and piscicolin 61) at levels equal to or exceeding levels in correspondence with the wild type cultures. Cuozzo et al. (2000) investigated II b class bacteriocin lactocin 705 from L. casei CRL 705 and reported about the required of both two peptides presence for the inhibitory activity.

The cloning, expression, and nucleotide sequence of the genes involved in the synthesis of pediocin PA-1 was reported by Marugg et al. (1992). The genes were cloned and expressed in E. coli and 5.6-kbp fragment from the plasmid was found to be necessary for the bacteriocin production. Hoover and co-workers (1989) noted about the surveyed 37 pediococci cultures for the antagonistic effect against eight List. monocytogenes strains and indicated that a bacteriocin effect of these LABs against List. monocytogenes may not be limited to a few industrial starter cultures. 15 strains containing the Lactobacillus, Pediococcus, Lactococcus, and Leuconostoc genera were examined for the inhibition against eight strains of List. monocytogenes (Harris et al., 1989) and only cell-free supernatants from Lactobacillus species UAL11, P. acidilactici PAC 1.0, and Leuconostoc species UAL14 were reported to inhibit all eight strains of List. monocytogenes. The addition of proteolytic enzymes caused the prevention of the inhibition. Ennahar et al. (1996) found out that Lactobacillus plantarum WHE 92 produce a bacteriocin identical to pediocin $\mathrm{AcH}$ from $P$. acidilactici $\mathrm{H}$, though pediocin AcH was produced more effectively in L. plantarum WHE 92 in the $\mathrm{pH}$ range of 5.0 to 6.0 as compared to $P$. acidilactici $\mathrm{H}$. Moreover, L. plantarum WHE 92 seems to have more effective means of antagonism against List. monocytogenes, since dairy products are normally higher than pH 5.0 (Hoover and Chen, 2005). Miller and co-workers (1998) applied PCR random mutagenesis for the construction of pediocin $\mathrm{AcH}$ amino acid substitution mutants. One mutant peptide was found to have a 2.8 -fold higher activity against L. plantarum NCDO955, while other mutations were inactive and shown a reduced antagonism. Johnsen et al. (2000) increased the stability of pediocin PA-1 with the replaced methionine residue with alanine, isoleucine, or leucine in order to protect from oxidation, since this peptide was found to lose its activity while stored as refrigeration or ambient temperatures.

Lacticin 3147 is a two peptide bacteriocin with a broad-spectrum activity and genetically resides on a self-transmissable plasmid that can be moved to other lactococci strains (Ross et al., 2000). McAuliffe and co-workers (1999) reported about a 3-log10 reduction in CFU/g of List. monocytogenes with the used Lc. lactis subs. lactis culture producing lacticin 3147. Bacteriocin S50 is another antimicrobial compound produced by lactococci, though it has a relatively narrow activity spectrum (Hoover and Chen, 2005). Lacticin FS92, containing 32 amino acids, is a heat-stable bacteriocin and appears to be active against List. monocytogenes as noticed by Mao et al. (2001). List. monocytogenes resistant mutants were found to remain sensitive to lacticin FS92, but not to pediocin PA-1, curvaticin FS47 and lacticin FS56. The susceptibility of List. monocytogenes, List. innocua, and List. seeligeri strains was found to strain-dependent at each $\mathrm{pH}$ examined in response to lactocin 705, enterocin CRL35, and nisin (Castellano et al., 2001).

\section{Optimization of media and growth conditions for increased bacteriocin production}

The incorporation of bacteriocins as a biopreservative ingredient into model food systems has been studied extensively and has been shown to be effective in the control of pathogenic and spoilage microorganisms (Neysen and De Vuyst, 2005). LAB can also be 
considered as protective cultures because they improve the microbiological quality as well as the safety of the food (Messens and De Vuyst, 2002) and can be a way to prevent product spoilage (Verluyten et al., 2004a). Lactic acid bacteria (LAB) are a group of microorganisms nutritionally exigent. They need a wide range of nutrients to grow and synthesize metabolic products, some nutritional requirements usually being strain specific. De Man-Rogosa-Sharpe (MRS) and yeast autolysate-peptone-tryptone-tween 80glucose (LAPTg) are standard culture media commonly used to support the growth of lactobacilli in the starting point of their cultivation. These media contain carbon and energy sources (carbohydrates, e.g. glucose), complex nitrogen sources (yeast extract, meat extract, tryptone and peptone) and supplements derived from oleic acid (Tween 80). MRS also includes inorganic and organic salts that have shown a stimulating effect or are essential for the growth of most of the species of this genus. Different components of culture media strongly affect the growth and bacteriocin production of several microorganisms that are mainly considered for food applications and must be included in fermentation processes, which are used on a production scale. Extruded wheat material is one of the candidates to be included as fermentation media for cultivation of bacteriocins producing LAB (Lactobacillus sakei MI806, Pediococcus pentosaceus MI810 and Pediococcus acidilactici MI807), previously isolated from spontaneous Lithuanian sourdoughs, in fermented products preparation formula for wheat bread production to have a higher positive effect compared with the control medium on LAB growth and their antimicrobial activities (Juodeikiene et al., 2011).

Frequently, the conditions that lead to high bacteriocin production are similar to those prevailing during food fermentation processes (Leroy et al., 2002; Delgado et al., 2005; Neysen and De Vuyst, 2005). Bacteriocin production is usually proportional to growth and shows primary metabolite kinetics (Moretro et al., 2000) but often the correlation is weak (Delgado et al., 2005) and this is particularly evident for bacteriocins produced during the stationary phase (Jim'enez-D'1az et al., 1993). Food preservation using in situ bacteriocin production requires a better understanding of the relationship between growth and bacteriocin production. Different bacteriocin exhibits different inhibition profile on food spoilage and pathogenic microorganisms. Therefore, they could be natural replacements for synthetic food preservatives. In order to increase the productivity of the bacteriocins, a better understanding on the factors affecting their production is essential.

Bacteriocin titres change with environmental factors (Leal-S'anchez et al., 2002; Delgado et al., 2005), such as $\mathrm{pH}$, temperature, and $\mathrm{NaCl}$ and ethanol concentrations. These environmental factors may influence growth negatively and thereby the secretion of the induction factor (Leal-S'anchez et al., 2002). Further, it has been suggested that some environmental factors reduce the binding of the induction factor to its receptor (Delgado et al., 2005). Bacteriocin production is strongly dependent on $\mathrm{pH}$, nutrient sources and incubation temperature. Activity levels do not always correlate with cell mass or growth rate of the producer (Kim et al., 1997; Bogovic-Matijasic \& Rogelj, 1998). Increased levels of bacteriocin production are often obtained at conditions lower than required for optimal growth (Bogovic-Matijasic \& Rogelj, 1998; Todorov et al., 2000; Todorov \& Dicks, 2004). Understanding the influence of food-related environmental factors on the induction of bacteriocins is essential for the effective commercial application of bacteriocin-producing $\mathrm{LAB}$ in the preservation of foods.

Leal et al. (1998) optimized the production of bacteriocins by Lactobacillus plantarum LPCO10 to allow the use of bacteriocins as natural food additives in canned vegetables and other 
food systems. Results obtained indicated that the best conditions for bacteriocin production were shown with temperatures ranging from $22{ }^{\circ} \mathrm{C}$ to $27 \mathrm{oC}^{\circ}$, salt concentration from 2.3 to $2.5 \%$, and L. plantarum LPCO10 inoculum size ranging from $10^{7.3}$ to $10^{7.4} \mathrm{CFU} / \mathrm{ml}$, fixing the initial glucose concentration at $2 \%$, with no aeration of the culture. Under these optimal conditions, about $3.2 \times 10^{4}$ times more bacteriocin per liter of culture medium was obtained than that used to initially purify plantaricin S from L. plantarum LPCO10 to homogeneity.

Delgado A. et al. (2007) by modeling studied the effects of some environmental factors on bacteriocin production by Lactobacillus plantarum 17.2b. Bacteriocin production by $L$. plantarum $17.2 \mathrm{~b}$ was very sensitive to environmental conditions and uncoupled from growth. Maximum production required suboptimal growth temperatures, $\mathrm{pH}$ values above growth's optimum and no $\mathrm{NaCl}$.

Many studies have focused on optimization of media and growth conditions of LAB for increased bacteriocin production. They have generally focused on the effects of $\mathrm{pH}$, temperature, composition of the culture medium, and general microbial growth conditions (in vitro as well as in natural fermentations) on maximal bacteriocin production (FAO-WHO, 2002; ANVISA, 2010; Cruz et al., 2009; Silveira et al., 2009; Minei et al., 2008; Galvez et al., 2008). By supplementing the medium with growth limiting factors, such as carbohydrates, nitrogen, vitamins and potassium phosphate, or by adjusting the medium $\mathrm{pH}$, levels of bacteriocin production is often increased.

Several mechanisms have been proposed for the bacteriocins activity: alteration of enzymatic activity, inactivation of anionic carriers through the formation of selective and non-selective pores and inhibition of spore germination (Parada et al. 2007; Martinez and De Martinis, 2006). Powell et al. (2006), Todorov and Dicks (2005a), (2005b), (2006a), (2006b), Todorov et al. (2000), (2007a), (2007b), (2004) and Todorov (2008) reported higher bacteriocin production levels for L. plantarum ST194BZ, L. plantarum ST13BR, L. plantarum ST414BZ, L. plantarum ST664BZ, L. plantarum ST23LD, L. plantarum ST341LD, L. plantarum 423, L. plantarum AMAK, L. plantarum ST26MS, L. plantarum ST28MS, L. plantarum ST8KF, L. plantarum ST31 in optimized growth media.

In general, the bactericidal/bacteriostatic action of bacteriocins encompasses the increased permeability of the cytoplasmic membrane of the target cells for a broad range of monovalent cations (e.g. $\mathrm{Na}^{+}, \mathrm{K}^{+}, \mathrm{Li}^{+}, \mathrm{Cs}^{+}, \mathrm{Rb}^{+}$and choline) leading to the destruction of proton motive force by dissipation of the transmembrane $\mathrm{pH}$ gradient and eventually to the cell death (Simova et al., 2009; Oppegård et al., 2007). The bactericidal or bacteriostatic activity possessed by bacteriocins is influenced by the following factors: bacteriocin dose and purification degree, physiological status of the indicator cells (e.g. growth phase) and experimental conditions (e.g. temperature, $\mathrm{pH}$, presence of agents disrupting cell wall integrity and other antimicrobial compounds) (Deraz et al., 2007; Cintas et al., 2001). An increased antibacterial activity of non-lanthionine-containing bacteriocins at low $\mathrm{pH}$ can be explained by the following factors: (1) more molecules are available to interact with the sensitive cells due to a lesser probability of the aggregation of hydrophilic peptides; (2) more molecules are available for the bactericidal action, since fewer molecules remain bound to the wall; (3) an enhanced capacity of hydrophilic bacteriocins to pass through hydrophilic regions of the cell wall of the sensitive bacteria; (4) an inhibited interaction at higher $\mathrm{pH}$ values between the non-lanthionine-containing bacteriocins and putative membrane receptors (Parada et al., 2007). 
These studies highlight the possibility of increase antimicrobial activity of fermented products with the aim to improve food safety and quality characteristics. Besides the optimization of bacteriocin production and enhancement of its activity are economically important to reduce the production cost.

\section{Application of bacteriocins producing LAB for improving some safety characteristics of plant products}

\subsection{Possibilities to prolong microbiological spoilage of bread using novel BLIS producing LAB}

Knowledge of fermenting microorganisms plays a defining role in the process of fermentation standardization and it is essential to have an exhaustive view of microbial interactions. The development of starter cultures for food fermentations follows a multidisciplinary approach and requires a thorough ecological study of these ecosystems. $\mathrm{LAB}$ are fundamental for the fermented product properties such as lactic fermentation, proteolysis, synthesis of volatile compounds, anti-mould and antiropiness effect. Since LAB are found to be the dominant microorganisms in sourdoughs, the rheology, flavour and nutritional properties of sourdough-based baked products greatly rely on their activity (Corsetti at al., 2003; Hammes and Gänzle, 1998; Gobbetti et al., 2005). Sourdough is used as an essential ingredient for acidification, leavening and production of flavour compounds and biopreservation of bread (Sadeghi, 2008; De Vuyst, 2007; Katina et al., 2005; Hansen, 2004; Clarke et al., 2004). In bakery practice, sourdough is usually sustained by repeated inoculation, whereby a reproducible and controlled composition and activity of the sourdough microflora is paramount to achieve a constant stability of sourdough as well as a constant quality of the end-product. Besides, many researchers have reported about the high resistance of sourdough breads to the microbiological spoilage by moulds and rope-forming bacilli (Valerio et al., 2009; Hassan and Bullerman, 2008; Sadeghi, 2008; Ryan et al., 2008; Mentes et al., 2007). Mould causes mouldiness and bacteria belonging to the genus Bacillus (Şimşek et al., 2006) are capable of causing massive economic losses due to the considerable resistance allowing them to survive food processing (Errington, 2003; Driks, 2002). The bacterial spoilage of bread, known as ropiness, occurs as an unpleasant fruity odour (Mentes et al., 2007), and is still of major economic concern in the baking industry.

\subsubsection{Rope production in bread}

Ropiness is mainly caused by Bacillus subtilis and Bacillus licheniformis (Collins et al., 1991) which reportedly originate from the raw materials, the bakery atmosphere and equipment surfaces (Bailey and von Holy, 1993). These strains are also known to be food-borne pathogens when present at levels of $105 \mathrm{CFU} / \mathrm{g}$ in bread crumb (Kramer and Gilbert, 1989). Bacillus is a genus of rod-shaped, endospore-forming aerobic or facultatively anaerobic, Gram-positive bacteria (in some species cultures may turn Gram-negative with age) and a member of the division Firmicutes. Many species of the genus exhibit a wide range of physiologic abilities that allow them to live in every natural environment. Under stressful environmental conditions, the cells produce oval endospores that can stay dormant for extended periods (Ravel and Fraser, 2005; Kunst et al., 1997). Bacteria belonging to the genus Bacillus are capable of causing economic losses to the baking industry due to the food spoilage condition known as rope (Valerio et al., 2008; Thompson et al., 1993). The 
predominant species involved in bread spoilage are Bacillus subtilis and B. licheniformis, though B. pumilus, B. megaterium and B. cereus are implicated as well (Şimşek et al., 2006; Rosenkvist and Hansen, 1995; Collins et al., 1991). These strains are also known to be foodborne pathogens when present at levels of 105 CFU/g in bread crumb (Kramer and Gilbert, 1989). Ropiness is noticed as an unpleasant odour, followed by a soft and sticky bread crumb caused by the enzymatic degradation and the production of extracellular slimy polysaccharides (Sadeghi, 2008; Valerio et al., 2008; Pepe et al., 2003).

Figure 4 illustrates an example of -ropy bread. B. subtilis spores have been isolated from ropy bread, meanwhile contamination of Bacillus have been reported to originate from raw materials, bakery environments and also from additives, including yeast, bread improvers, and gluten (Thompson et al., 1993; Rosenkvist and Hansen, 1995; Collins et al., 1991; Sorokulova et al., 2003; Bailey and von Holy, 1993).

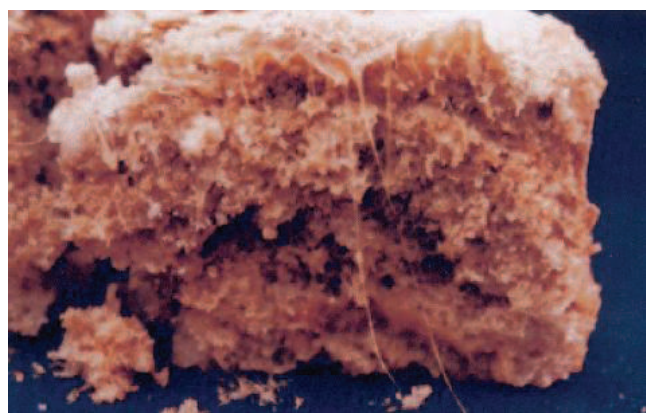

Fig. 4. Rope production in bread.

B.subtilis spores being heat resistant can survive the baking process, since the maximum temperature in the loaf centre remains $97^{\circ} \mathrm{C}$ to $101^{\circ} \mathrm{C}$ for a few minutes (Östman, 2002; Rosenkvist and Hansen, 1995). During subsequent exposure to the warm $\left(25^{\circ} \mathrm{C}\right.$ to $\left.30^{\circ} \mathrm{C}\right)$ and humid (water activity, $\geq 0.95$ ) environmental conditions Bacillus spores germinate causing bread spoilage (Volavsek et al., 1992). The spore germination and growth of Bacillus vegetative cells during storage strongly depend on the water activity, $\mathrm{pH}$ and temperature (Condón et al., 1996; Quintavalla and Paroli, 1993).

\subsubsection{Spore formation in Bacillus subtilis}

Bacterial spores are very specialized, differentiated cell types and can survive the adverse conditions (e.g. starvation, high temperatures, ionizing radiation, mechanical abrasion, chemical solvents, detergents, hydrolytic enzymes, desiccation, $\mathrm{pH}$ extremes and antibiotics). Spores can cause massive problems in the food industry due to the considerable resistance allowing them to survive food processing and conservation methods (Errington, 2003; Driks, 2002).

The mature heat-resistant spore formation takes approx. 8 hours from the initial time of starvation. Numerous alterations in gene expression and a variety of physiological and morphological changes characterize the process of sporulation (Grossman and Losick, 1988). B. subtilis has been used as a model for the sporulation (the process of spore formation) studies (Errington, 2003; Eichenberger et al., 2004; Piggot and Hilbert, 2004; Phillips and 
Strauch, 2002). Spore formation is a unique and complex process and can be divided into stages 0, II, III, IV, V, and VI (Grossman and Losick, 1988) involving asymmetric cell division, engulfment of the smaller cell and sacrifice of the original bacterial cell for the production of a single spore (Figure 5).

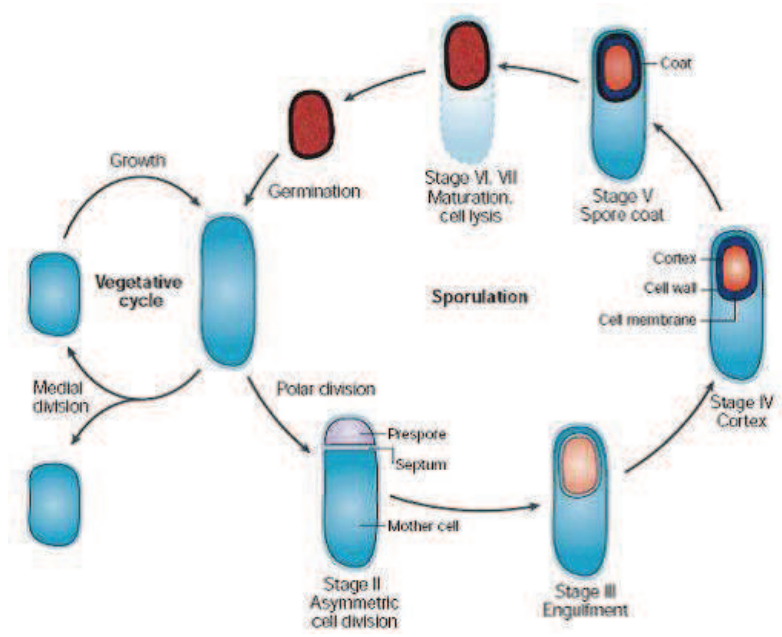

Fig. 5. The sporulation cycle of Bacillus subtilis.

Stage 0 is characterized as the cell commitment to sporulation that leads to the building of a septum (stage II). As a cell begins the process of forming an endospore, it divides asymmetrically, resulting in the creation of two compartments (the larger mother cell and the smaller prespore). Afterwards, the degradation of thepeptidoglycan in the septum occurs and mother cell engulfs the prespore, leading to the formation of a cell within a cell (stage III). The synthesis of the endospore-specific compounds, formation of the cortex and deposition of the coat (stages IV and V) proceeds due to the activities of the mother cell and prespore. Stages IV and V are followed by the final dehydration and maturation of the prespore (stages VI and VII). Finally, the mother cell is destroyed in a programmed cell death, and the endospore is released into the environment. The endospore remains dormant until it senses the return of more favourable conditions (Errington, 2003; Grossman and Losick, 1988; Phillips and Strauch, 2002).

\subsubsection{Strategy for the control of Bacillus spp. by BLIS producing LAB in bread production}

The initial Bacillus spore counts could be reduced by the recommended control procedures such as raw material quality, good sanitation of bakery equipment, stringent temperature control during baking, production cooling and storage environments (Bailey and von Holy, 1993; Viljoen and von Holy, 1993). The use of chemical preservatives (propionic and acetic acids) was reported to be one of the ways for the inhibition of Bacillus germination and growth in bread, although the current trend is to reduce the levels of these substances (Pattison et al., 2004; Marín et al., 2002). The increase in acidity by using traditional sourdough fermentation is an effective way to limit the germination and growth of rope 
forming bacteria (Sadeghi, 2008). Röcken (1996) reported about the enhanced thermal inactivation of $B$. subtilis spores by using an increased sourdough contents. Katina and coworkers 2005 examined the ability of LAB to inhibit the growth of rope forming strains in wheat bread and announced about the growth inhibition of B. subtilis and B. licheniformis by Lactobacillus plantarum VTT E-78076 and Pediococcus pentosaceus VTT E-90390. The added heat-treated cultures of L. plantarum E5 and Leuc. mesenteroides A27 were reported to prevent the growth of approximately $10^{4}$ rope-producing $B$. subtilis $\mathrm{G} 1$ spores per $\mathrm{cm}^{2}$ on bread slices for more than 15 days (Pepe et al., 2003). The inhibition of the rope spoilage of wheat bread was observed with the added 20-30 g of sourdough/100 $\mathrm{g}$ of wheat dough (Katina, K. et al., 2002). Kingamkono and co-workers (1994), Svanberg and co-workers (1992) shown that food fermentation by LAB to $\mathrm{pH} 4.0$ or lower inhibited the growth of Bacillus as well as other pathogenic microorganisms. Suomalainen and Mäyrä-Makinen (1999) reported about the inhibitory effect of Lactobacillus rhamnosus LC705 against Bacillus spp. in bakery products. Bogovič-Matijašić and co-workers (1998) found out the antimicrobial activity of Lactobacillus acidophilus LF221 producing two bacteriocins against different pathogens including B. cereus. Røssland and co-workers (2003) demonstrated that a rapid decrease in pH during $\log$ phase of fermentation was related with the B. cereus growth inhibition. Meanwhile B. cereus sporulated and existed as endospores with the $\mathrm{pH}$ reduced at a slower rate in early $\log$ phase.

Several studies have been dedicated for the analysis of the antimicrobial activity of LAB and their produced bacteriocins, and have reported that the antifungal activity of LAB is lost after treatment with proteolytic enzymes. Batish et al. (1989) suggested that the antifungal substance produced by a LAB isolate was of proteinaceous nature since activity disappeared with proteinase treatment. Roy et al. (1996) isolated a Lactococcus lactis subsp. lactis with antagonistic activity against several filamentous fungi, that were lost after enzymatic treatment with chymotrypsin, trypsin and pronase Gourama (1997a) found that the inhibitory effect of a Lactobacillus casei strain against two Penicillium species was slightly reduced by treatment with trypsin and pepsin. Gourama and Bullerman (1995, 1997b) showed that a commercially available silage inoculant with a combination of Lactobacillus species (L. plantarum, L. delbrueckii subsp. bulgaricus and L. acidophilus) had antifungal and antiaflatoxin activity against A. flavus. The inhibitory activity was sensitive to treatments with trypsin and alpha-chymotrypsin, and it was concluded that the activity was due to a small peptide.

The changes in LAB antimicrobial effect upon the interactions with the enzymes is very important in the baking industry where commercial enzyme preparations often are used for fermentation processes intensification and recently became one of the research topics.

In one of the studies (Digaitiene et al., 2005), 270 bacterial strains were isolated from spontaneous sourdoughs and of these, five LAB (Lactobacillus sakei MI806, Pediococcus pentosaceus MI808, MI809 and MI810, Pediococcus acidilactici MI807) isolates were found to produce BLIS (sakacin 806, pediocin 808, 809, 810 and pediocin Ac807 respectively). Isolates of new bacteriocins producing LAB strains depend for subclass II. The results of inhibitory spectra studies and $\mathrm{pH}$ sensitivity analysis indicated that the BLIS under investigation were different from each other. These novel BLIS (sakacin 806, pediocin 808, pediocin 809, pediocin 810 and pediocin Ac807) have been tested for their antimicrobial activity against $B$. subtilis, one of the most important micro-organisms responsible for ropiness in bread; 
furthermore their sensitivity to various baking enzymes has been examined (Narbutaite et al., 2008). Antimicrobial activity was tested using an overlay assay method; the results showed that the BLIS studied here were effective against $B$. subtilis. To our knowledge, this is the first report of BLIS-producing LAB isolated from sourdoughs which are active against B. subtilis.

Bacteriocins have gained importance as natural biopreservatives for the control of spoilage and pathogenic organisms in foods. Latest studies highlights the possibility of using LAB exhibiting antimicrobial activity against $B$. subtilis in sourdough bread making, a desirable characteristic when selecting for more competitive starters. The strains described here can have an impact when used as starter cultures for traditional sourdough fermentation by delaying spore germination and inhibiting the outgrowth of B. subtilis. This opens up the possibility of using such LAB on an industry scale. Future work will also focus on obtaining the amino acid sequences of the BLIS presented here.

\subsection{Potential of lactic acid bacteria to degrade biogenic amines in different fermentation media}

A variety of fermented foods especially protein-rich foods e.g. fermented vegetables, legume products, beers and wines contain biogenic amines (BAs) (Kalač et al., 2002). During the fermentation process protein breakdown products, peptides and amino acids, used by spoilage and also by the fermentation microorganisms represent precursors for BAs formation (Hernandez-Jover et al., 1997; Bodmer et al., 1999). BAs are formed through the decarboxylation of specific free amino acids by exogenous decarboxylases released from the microbial population associated with the raw material.

Some biogenic amines such as histamine (HIS), tyramine (TYR), putrescine (PUT) and cadaverine (CAD) are important for their physiological and toxicological effects on the human body. They may exert either psychoactive or vasoactive effects on sensitive humans. Histamine is physiologically the most important BA. Histamine has been found to cause the most frequent food-borne intoxications associated with BAs; it acts as a mediator and is involved in pathophysiological processes such as allergies and inflammations (Gonzaga et al, 2009). Tyramine can evoke nausea, vomiting, migraine, hypertention and headaches (Shalaby, 1996). Putrescine and cadaverine can increase the negative effect of other amines by interfering with detoxification enzymes that metabolize them (Stratton et al., 1991). The consumption of foods with high concentrations of BAs can induce adverse reactions such as nausea, headaches, rashes and changes in blood pressure (Ladero et al., 2010).

The main BAs associated with such fermented plant product as wine are HIS, TYR and PUT (Ancin-Azpilicueta et al., 2008). Their presence in wine is considered as marker molecules of quality loss, and some EU countries even have recommendations for the amount of histamine acceptable in wine which impacts on the import and export of wines to these countires. Most fermented foods, such as cheese, fermented sausages and beer, which are consumed more frequently than wines, have biogenic amine content (Fernandez et al., 2007). However, the precence of alcohol in wine may enhance the activity of amines because it inhibits monoamine oxidase enzymes. These enzymes depending for the detoxification system in the intestinal tract of mammals convert amines into non-toxic products, which are further excreted out of the organism. 
Regarding fruits and vegetables relatively low levels of biogenic amines were found in fruit juice and canned fruit/vegetable samples. The same tendency has been noticed in other publications, but sometimes the results are controversial. Moret et al., (2005) showed that vegetables generally contained low levels in biogenic amines $\left(0.1-9.6 \mathrm{mg} \mathrm{kg}^{-1}\right)$ while Kalač et al., (2002) found relatively high levels of the amines in vegetables $\left(0.8-52.5 \mathrm{mg} \mathrm{kg}^{-1}\right)$. The polyamines PUT and spermidin (SPM) are practically ubiquitous in all vegetables at a few $\mathrm{mg} / 100 \mathrm{~g}$ of fresh weight and TYR is less widespread in vegetables (Kalač et al., 2002; Moret et al., 2005). They are implicated in a number of physiological processes, such as cell division regulation, plant growth, flowering, fruit development, response to stress and senescence (Bouchereau et al., 2000). Moreover, although PUT, SPD and other biogenic amines are generated in low quantities in most canned vegetables/fruits, they are not the primary metabolic products produced by the fermenting organisms (Stratton et al., 1991).

With the exception of tempe (Saaid et al., 2009) and taucu, relatively low levels of biogenic amines are found in the soy bean products tested. Studies by Mower and Bhagavan (1989) showed higher level of TYR $\left(450 \mathrm{mg} \mathrm{kg}^{-1}\right)$ in salted black beans. The quantitative analysis of fermented products prepared for wheat bread production revealed that tyramine (32.6-215.8 $\mathrm{mg} \mathrm{kg}-1)$, histamine (20.8-96.7 $\left.\mathrm{mg} \mathrm{kg}^{-1}\right)$, and putrescine (33.7-195.2 $\mathrm{mg} \mathrm{kg}^{-1}$ ) showed as being the major occurring BAs (Bartkiene et al., 2011). Since several varieties of molds, yeasts and lactic acid bacteria are involved in the fermentation processes of such products and the raw material (soy bean) contains considerable amounts of protein, the formation of various amines might be expected during the fermentation (Shalaby, 1996). Studies have shown that biogenic amines in fermented soy bean products are most likely formed by the lactic microflora that is active during fermentation (Kirschbaum et al., 2000). TYR and HIS have been found at various levels in such products (Stratton et al., 1991). The variability of biogenic amines levels in the commercial fermented soy bean products samples had been attributed to the variations in manufacturing processes; variability in the ratio of soy bean in the raw material, microbial composition, conditions and duration of fermentation (Shalaby, 1996).

Knowledge concerning the origin and factors involved in BAs production in fermented products e.g. wine is well documented, and recently several reviews on this topic have been published (Costantini et al., 2009; Moreno-Aribas and Polo, 2010). They are generated either as the result of endogenous decarboxylase-positive microorganisms in raw materials or by the growth of contaminating decarboxylase-positive microorganisms in fermented products. With regards to wine microorganisms, a large amount of literature is available on the production of BAs. Several research group support the view that biogenic amines are formed in winemaking mainly by lactic acid bacteria (LAB) due to the decarboxilation of the free amino acids (Constantini et al., 2006; Lucas et al., 2008). The levels of BAs usually increase during fermentation due to decarboxylase activity of the LAB used as starter culture. Low acid conditions, such as those occurring during fermentation, favour the decarboxylation of amino acids (De las Rivas et al., 2005). The levels of free amino acids usually increase in fermented products during fermentation due to the action of endogenous and exogenous proteases through proteolysis processes (Hughes et al., 2002). It is thought that proteolysis might provide the nutrient for spoilage microorganisms, leading to a promoted growth of those microorganisms (Riebroy et al., 2004).

In this context, recently published paper (Garcia et al., 2011) reports novel data about the presence of histamine-, tyrosine- and putrescine-degrading enzymatic activities of wine- 
associated LAB. Of particular interest are the results concerning the degradation of putrescine, since no such degrading ability of any food LAB has previously been reported. The isolates tested (42 strains Oenococcus oeni, 7 strains Pediococcus parvulus, 4 strains $P$. pentosaceus, 6 strains Lactobacillus plantarum, 9 strains L. hilgardi, 3 strains L. zeae, 7 strains L. casei, 5 strains L. paracasei and 2 strains Leuconostoc mesenteroides) belong to the principal species of wine LAB and other related ecosystems and were selected because they came from wine cellars that often suffer from the problem of BAs in their wines (Moreno-Aribas and Polo, 2010). In this study the most potent amine-degrading species detected were $L$. plantarum, P. paroulus and, in particular, P. pentosaceus and L. casei, in spite of the fact that strains of these last species have never be reported to degrade histamine, tyramine and/or putriscine. None of the strains were able to produce these BAs as they did no show the decarboboxylase activity necessary for the production of these compounds in wine. However, this potential for histamine, tyramine and/or putrescine degradation among wine LAB does not appear to be very frequent, since out of the 85 strains examined, only nine displayed noteworthy amine-degrading activity in culture media. Further studies using other LAB species and/or strains may enable more potent amine-degrading enzyme producers to be identified. However, it was observed that positive strains displayed aminedegrading activity against several biogenic amines simultaneoustly, in accordance with previous works that also reported the presence of either one or two amine oxidases in other food fermenting microorganisms, such as Micrococcus varians and Staphylococcuscarnosus (Leuschner et al., 1998).

The fact that active bacteria which were able to significantly reduce the concentration of BAs in the conditions used in the study came from different fermentation media such as young wine, wood- aged wines, sherry wines (Table 1), suggest that there are ecological niches for the isolation of potential amine-degrading bacteria.

\begin{tabular}{|l|c|c|c|}
\hline \multirow{2}{*}{ Strains } & \multicolumn{3}{|c|}{ Degradation, $\%$ a, $\mathrm{b}$} \\
\cline { 2 - 4 } & Histamine & Tyramine & Putrescine \\
\hline L. casei IFI-CA-52 & 54 & 55 & 65 \\
\hline L. hilgardi IFI-CA-41 & n.e. & n.e. & 20 \\
\hline L. plantarum IFI-CA-26 & 33 & n.e. & 24 \\
\hline L. plantarum IFI-CA-54 & 23 & 17 & 24 \\
\hline O. oeri IFI-CA-32 & 12 & n.e. & 16 \\
\hline P. parvulus IFI-CA-30 & 20 & 15 & 53 \\
\hline P. pentosaceous IFI-CA-30 & 10 & 12 & 49 \\
\hline P. pentosaceous IFI-CA-83 & 19 & 22 & 39 \\
\hline P. pentosaceous IFI-CA-86 & n.e. & 54 & 69 \\
\hline
\end{tabular}

a Activity is expressed as a percentage of control without strain and according to HPLC quantitative biogenic amine results.

${ }^{b}$ Mean value $(\mathrm{n}=3)$; n.e. : no effect was observed.

Table 1. Percentage of degradation of the biogenic amines (histamine, tyramine and putrescine) by wine-associated LAB in culture media

Recently, homofermentative Pediococcus acidilactici were isolated from spontaneous rye sourdoughs and characterised as producing pediocin Ac807 with antimicrobial activity 
against Bacillus subtilis (Digaitiene et al., 2005; Narbutaite et al., 2008). Since fermentation by using $P$. acidilactici could improve or modify flavour, taste, and texture of used plant additives for wheat bread production, the safety characteristics of fermented products rich in proteins are not always predictable. Therefore the BAs investigation in untreated whole lupine flours and fermented products of different lupines species (Lupinus angustifolius and Lupinus luteus) after spontaneous fermentation and fermentation by $P$. acidilactici has been carried out (Bartkiene et al., 2011). This study showed that the BAs levels were found to be lower after fermentation (by $17 \%$ ) of L. luteus flour by P. acidilactici. Also the total amount of BAs was significantly reduced $(25 \%)$ during spontaneous fermentation of L. luteus flour compared to non-treated samples. Opposite to the L. luteus, fermentation of L. angustifolius flour led to an increase of $20.5 \%$ and $44 \%$ of total amount of BAs in spontaneous and $P$. acidilactici sourdoughs, respectively. The different BAs in fermented products, which have been prepared using different kinds of lupine can be explained by the quality of the raw material and /or by formation during the fermentation process involving microorganisms and these results are in agreement with previous research (Silla Santos, 1996).

The presented results agree to the findings that the use of decarboxylase negative microorganisms, e.g. LAB as starter cultures could be an important factor to be considered in order to reduce the levels of BAs in fermented foods.

\subsection{Possible approaches of LAB and enzymes to biodegradation of mycotoxins}

Mycotoxins are secondary metabolites produced by a wide variety of filamentous fungi, including species from the genera Aspergillus, Fusarium and Penicillium. They cause nutritional losses and represent a significant hazard to the food and feed chain. Humans have long been exposed to mycotoxins by several different routes: directly, via foods of plant origin, including cereals from which bread and bakery products are derived; by air (both indoors and outdoors); or indirectly, through foods of animal origin. Many countries, therefore, have established measures to safeguard the health of consumers by establishing regulations for food and feed. The most economically important mycotoxins occurring in food and feed are aflatoxins, ochratoxin A, patulin, and the Fusarium toxins (zearalenon, trichothecenes, fumonisins etc.) (Chassy, 2010).

Principally, there are three possibilities to avoid harmful effect of contamination of food and feed caused by mycotoxins: (1) prevention of contamination, (2) decontamination of mycotoxin-containing food and feed, and (3) inhibition of absorption of mycotoxin content of consumed food into the digestive tract (Halász et al., 2009).

The theoretically soundest approach of prevention is doubtless to breed cereals and other food and feed plants for resistance to mould infection and consequently exclude mycotoxin production. Particularly in breeding wheat and corn, significant improvement of resistance has been achieved. The identification of microbial species (and genes coding enzymes degrading mycotoxins) allows transfer of these genes into plants and production of such enzymes by transgenic plants. In this way, the safety problems connected with the use of live microorganisms may be avoided.

Another practical approach to prevention of mycotoxin contamination is the inhibition of the growth of molds and their production of mycotoxins. First, optimal harvesting, storage and processing methods, and conditions may be successful in prevention of mold growth. 
Although the primary goal is the prevention of mycotoxin contamination, mycotoxin formation appears to be unavoidable under certain adverse conditions.

Treatment of grains by some chemicals to prevent mycotoxin formation is also possible. Most of these compounds work by inhibiting fungal growth. For example, approximately one hundred compounds have been found to inhibit aflatoxin production. Two extensively studied inhibitors of aflatoxin synthesis are dichlorvos (an organophosphate insecticide) and caffeine. As reported by (Halász et al., 2009) some surfactants have been found to suppress the growth of Aspergillus flavus and aflatoxin synthesis.

When contamination cannot be prevented, physical and chemical decontamination methods have been employed with varying success in the past, principally for feed. Whichever decontamination strategy is used, it must meet some basic criteria:

- the mycotoxin must be inactivated or destroyed by transformation to non-toxic compounds;

- fungal spores and mycelia should be destroyed, so that new toxins are not formed;

- the food or feed material should retain its nutritive value and remain palatable;

- the physical properties of raw material should not change significantly; and

- it must be economically feasible / the cost of decontamination should be less than the value of contaminated commodity.

Partial removal of mycotoxin may be achieved by dry cleaning of the grain and in the milling process, as well. Milling led to a fractionation, with increased level of mycotoxin in bran and decreased level in flour. The majority of mycotoxins are heat-stable so heat treatment, usually applied in food technology, does not have significant effect on mycotoxin level.

Efforts were made in several countries to find an economically acceptable way of destruction of mycotoxins into non-toxic products using different chemicals such as alkali and oxidative agents. Although such treatment reduces nearly completely the mycotoxin concentration, these chemicals also cause losses of some nutrients and such treatment is too drastic for grain destined for food uses.

Although the different methods used at present have been to some extent successful, most methods have major disadvantages, starting with limited efficacy to losses of important nutrients and generally with high costs.

More recently, biological decontamination and biodegradation of mycotoxins with microorganisms or enzymes, have been used (He et al., 2010; Juodeikiene et al., 2011). In this case no harmful chemicals where used, so no significant losses in nutritive value and palatability of decontaminated food and feed occurred. Today, ruminants appear to be a promising potential source of microbes or enzymes for use in the biotransformation of mycotoxins.

One of the most frequently used strategies for biodegradation of mycotoxins includes isolation of microorganisms able to degrade the given mycotoxin and treatment of food or feed in an appropriate fermentation process. From the food safety point-of-view, fermentation with microorganisms commonly used in food production (fermentation with lactic acid bacteria, alcoholic fermentation, traditional fermentation of vegetable protein 
used in South Asia, etc.) should be preferred. Knowledge of enzymes that take part in degradation of mycotoxins opens some new approaches: (1) the production of genetically modified species of microorganisms commonly used in food production and their use for production of enzymes mentioned above; or (2) the transfer of genes coding for these enzymes to transgenic plants and use the plants for production of mycotoxin degrading enzymes.

In staple food such as bread and bakery products in the flour sector, yeast and lactobacilli now play an important role. It thus stands to reason that the same microbes and enzymes are the first to have been considered for use as detoxifying or decontaminating agents. This type of biodegradation could therefore prove a useful strategy for partially overcoming the problem of some mycotoxins. Indeed, this already takes place in bread and in sourdough processes (Bartkiene et al., 2008); and OTA in food can also undergo biodegradation (Abrunhosa et al., 2010) and certain antagonistic yeast strains can substantially degrade OTA. This might offer new possibilities for reducing this mycotoxin in bread and bakery products and their raw materials (Patharajan et al., 2011). The use of enzymes or engineered micro-organisms (provided that these are allowed by legislation) as processing aids in the bread and bakery sector would also prove beneficial. Genetic engineering technologies will improve the efficiency with which enzymes can be produced from these organisms, and will allow the production of engineered organisms which have the target genes. They will additionally increase the availability and bioavailability, and will improve the quality of the end product.

\subsubsection{Inhibition of mycotoxins biosynthesis by lactic acid bacteria}

Several papers dealing with the inhibition of mycotoxin biosynthesis by LAB have focused on aflatoxins (Thyagaraja \& Hosono, 1994). During cell lysis, it is possible that LAB releases molecules that potentially inhibit mould growth and therefore lead to a lower accumulation of their mycotoxins (Gourama \& Bullerman, 1995). These "anti-mycotoxinogenic" metabolites could also be produced during LAB growth. Gourama (1991), using a dialysis assay, demonstrated the occurrence of a metabolite that inhibits aflatoxin accumulation in Lactobacillus cell-free extracts. It was suggested that this inhibition of aflatoxin biosynthesis was not the result of a hydrogen peroxide production or a $\mathrm{pH}$ decrease (Karunaratne et al., 1990). These findings were consistent with those of Gourama (1991), who suggested that inhibition of aflatoxin biosynthesis by Lactobacillus cell free supernatants was probably due to specific bacterial metabolites. Coallier-Ascah and Idziak (1985) reported a significant reduction of aflatoxin biosynthesis by Lactobacillus cell free supernatants and suggested that this inhibition was related to a heat stable, low-molecular-weight inhibitory compound. Although Lactobacillus spp. were found to delay aflatoxin biosynthesis, other lactic strains such as Lc. lactis were found to stimulate aflatoxin accumulation (Luchese and Harrigan, 1990).

\subsubsection{Decontamination of mycotoxins using microorganisms by binding or degradation}

Biological detoxification of mycotoxins works mainly via two major processes, sorption and enzymatic degradation, both of which can be achieved by biological systems. Live microorganisms can absorb either by attaching the mycotoxin to their cell wall components or by 
active internalization and accumulation. Dead microorganisms too can absorb mycotoxins, and this phenomenon can be exploited in the creation of biofilters for fluid decontamination or probiotics (which have proven binding capacity) to bind and remove the mycotoxin from the intestine.

Another approach to the biological decontamination of mycotoxins involves their degradation by selected micro-organisms. Recently critical review on biological detoxification by (Dalié et al., 2009) summarized different and interesting aspects of the biological detoxification of mycotoxins.

Micro-organism detoxification can be performed in many different ways (Magan and Olsen, 2004):

- The entire organism can be used as a starter culture, as in the fermentation of beer, wine and cider, or in lactic acid fermentation of vegetables, milk and meat.

- $\quad$ The purified enzyme can be used in soluble or immobilized (biofilter) forms.

- The gene encoding the enzymatic activity can be transferred and overexpressed in a heterologous system; interesting candidates for this application include yeasts, probiotics and plants.

Biological methods have been applied for the biodegradation and decontamination of different mycotoxins.

Aflatoxins. As the first mycotoxins to be discovered, were also the first target in screening for microbial degradation. Several examples of the detoxification of the most common and important mycotoxins are reviewed. Almost 40 years ago, several species of microorganisms - including yeasts, moulds, bacteria, actinomycetes and algae - were screened for detoxification activity; based on this studies only one isolate was found, Flavobacterium auranotiacum, which significantly removed aflatoxin from a liquid medium (Ciegler et al., 1966).

Later aflatoxins decontamination during fermentation was reported in several cases. About $50 \%$ reduction in aflatoxins B1 and G1 has been reported during an early stage of miso fermentation. It was attributed to the degradation of the toxin by micro-organisms. Significant losses of aflatoxin B1 and ochratoxin A were observed during beer brewing (Chu et al., 1975). Detoxification of aflatoxin B1 occurred during the fermentation of milk by LAB and in dough fermentation during breadmaking. Digestive tract micro-organisms are able to reduce mycotoxin levels not only by binding and removal but also by detoxification.

Most data dealing with the effects of LAB on the accumulation of mycotoxins are related to aflatoxin-producing moulds. Wiseman and Marth (1981) revealed the existence of an amensalism relationship between Lc. lactis and A. parasiticus. When these authors added the spores of $A$. parasiticus to a 13-day-old culture of Lc. lactis, they observed the entire repression of aflatoxin production. When the fungal spore suspension and the lactic strain were inoculated simultaneously, an increase in aflatoxin production was observed. In contrast, Coallier-Ascah and Idziak (1985) showed an inhibition of aflatoxin accumulation when both microorganisms were simultaneously cultivated in Lab-Lemco tryptone broth (LTB). Addition of glucose to the cultivation medium during the conidiation phase of the mould did not restore the the production of aflatoxin. 
Several LAB have been found to be able to bind aflatoxin $B_{1}$ in vitro (Kankaanpää et al., 2000; Gratz et al., 2004), with an efficiency depending on the bacterial strain (Shah \& Wu, 1999). El-Nezami with co-workers (1998a) have evaluated the ability of five Lactobacillus to bind aflatoxins in vitro and have shown that probiotic strains such as Lb. rhamnosus GG and $L b$. rhamnosus LC-705 were very effective for removing aflatoxin $B_{1}$, with more than $80 \%$ of the toxin trapped in a $20 \mu \mathrm{g} / \mathrm{ml}$ solution (Haskard et al.,1998).

According to Coallier-Ascah and Idziak (1985), the inhibition of aflatoxin accumulation was not related to a $\mathrm{pH}$ decrease but rather to the occurrence of a low-molecular-weight metabolite produced by the LAB at the beginning of its exponential phase of growth. Inhibition of aflatoxin production by other LAB belonging to the genus Lactobacillus was also reported (Karunaratne et al., 1990). It was assumed that this inhibition resulted from the production of a metabolite different from hydrogen peroxide or organic acid (Gourama, 1991). Haskard wich co-wokers (2001) demonstrated that Lb. rhamnosus GG (ATCC 53103) and $L b$. rhamnosus LC-705 (DSM 7061) were able to eliminate aflatoxin $\mathrm{B}_{1}$ from the culture medium by a physical process.

Several studies have suggested that the antimutagenic and anti-carcinogenic properties of probiotic bacteria can be attributed to their ability to non-covalently bind hazardous chemical compounds such as aflatoxins in the colon (El-Nezami et al., 1998b; Gratz et al., 2004). Both viable and non-viable forms of the probiotic bacterium Lactobacillus rhamnosus GG effectively removed aflatoxin B1 from an aqueous solution (El-Nezami et al., 1998b). Since metabolic activation is not necessary, binding can be attributed to weak, non-covalent, physical interactions, such as association to hydrophobic pockets on the bacterial surface (Haskard et al., 2000). Coallier-Ascah and Idziak (1985) reported a significant reduction of aflatoxin biosynthesis by Lactobacillus cell free supernatants and suggested that this inhibition was related to a heat stable, low-molecular-weight inhibitory compound.

Ochratoxin-A (OTA) The major OTA producers in food and feed products are considered to be $A$. alliaceus, A. carbonarius, A. ochraceus, A. steynii, A. westerdijkiae, $P$. nordicum and $P$. verrucosum (Frisvad et al., 2006). These are mainly associated with agricultural crops preharvest, or in post harvest storage situations. Biological methods use microorganisms, which can decompose, transform or adsorb OTA to detoxify contaminated products or to avoid the toxic effects when mycotoxins are ingested. These are the technologies of choice for decontamination proposes because they present several advantages from being mediated by enzymatic reactions. For example, they are very specific, efficient, environmentally friendly, and they preserve nutritive quality.

Two pathways may be involved in OTA microbiological degradation (Abrunhosa et al., 2010). First, OTA can be biodegraded through the hydrolysis of the amide bond that links the L- $\beta$-phenylalanine molecule to the OTa moiety. Since OTa and L- $\beta$-phenylalanine are virtually non-toxic, this mechanism can be considered to be a detoxification pathway. Second, a more hypothetical process involves OTA being degraded via the hydrolysis of the lactone ring. In this case, the final degradation product is an opened lactone form of OTA, which is of similar toxicity to OTA when administered to rats. However, it is less toxic to mice and Bacillus brevis. Although this is hypothetical, it is likely to occur since microbiological lactonohydrolases, which undertake a similar transformation, are common. Several protozoal, bacterial, yeast and filamentous fungal species are able to biodegrade OTA. After success in clarifying the mechanism and degradation products of ochratoxin, 
three directions in recent research may be observed (1) possibilities of bacterial degradation, study of molds able to degrade this mycotoxin and identification and isolation of enzymes taking part in the degradation process.

Lactobacillus strains were demonstrated to eliminate $0.05 \mathrm{mg}$ OTA/L added to culture medium - in particular, L. bulgaricus, L. helveticus, L. acidophillus, eliminated up to $94 \%, 72 \%$ and 46\%, respectively, of OTA (Böhm et al., 2000); L. plantarum, L. brevis and L. sanfrancisco were reported to eliminate $54 \%, 50 \%$ and $37 \%$, respectively, of $0.3 \mathrm{mg}$ OTA/L after $24 \mathrm{~h}$ of incubation (Piotrowska and Zakowska, 2000). It is now generally accepted that OTA adsorption to the cells walls is the predominant mechanism involved in this OTA detoxification phenomenon by lactic acid bacteria (LAB). For example, adsorption effects were claimed by Turbic et al. (2002), who found that heat and acid treated cells from two Lactobacillus rhamnosus strains were more effective at removing OTA from phosphate buffer solutions than viable cells. The strains removed $36 \%$ to $76 \%$ in the buffer solution ( $\mathrm{pH} 7.4$ ) after $2 \mathrm{~h}$ at $37^{\circ} \mathrm{C}$. Similarly, Piotrowska and Zakowska (2005) verified that L. acidophilus and L. rhamnosus caused OTA reductions of $70 \%$ and $87 \%$ of $1 \mathrm{mg}$ OTA/L after five days at $37^{\circ} \mathrm{C}$, and that significant levels of the OTA were present in the centrifuged bacteria cells. Other LAB (L. brevis, L. plantarum and L. sanfranciscencis) also produced smaller decreases on OTA (approximately 50\%). Finally, Del Prete et al. (2007) tested 15 strains of oenological LAB in order to determine the in vitro capacity to remove OTA, and reported Oenococcus oeni as the most effective, with OTA reductions of $28 \%$. The involvement of cell-binding mechanisms was confirmed as (i) up to $57 \%$ of the OTA absorbed by the cells was recovered through methanol extraction from the bacteria pellets; (ii) crude cell-free extracts were not able to degrade OTA; and (iii) degradation products were not detected. Nevertheless, some authors consider that metabolism may also be involved. For example, Fuchs et al. (2008) confirmed that viable cells of $L$. acidophilus removed OTA more efficiently then unviable. A $L$. acidophilus strain was able to decrease $\geq 95 \%$ the OTA in buffer solutions ( $\mathrm{pH}$ 5.0) containing 0.5 and $1 \mathrm{mg}$ OTA/L when incubated at $37^{\circ} \mathrm{C}$ for $4 \mathrm{~h}$. In addition, a detoxification effect was also demonstrated since pre-incubation of OTA with this strain reduced OTA toxicity to human derived liver cells (HepG2) (Fuchs et al., 2008). Other L. acidophilus strains demonstrated only a moderate reduction in OTA contents suggesting that the effect was strain specific. In summary, some LAB adsorbs OTA by a strain specific cell-wall binding mechanism, although some undetected catabolism can also be involved. The detection of this OTA catabolism may only be possible with radiolabeled OTA.

The potential of LAB as mycotoxin decontaminating agents has been studied in different fermentation processes and reviewed (Shetty and Jespersen, 2006). The ochratoxin-A content, its fate during wine-making and possibilities of its degradation have been intensively studied. Overviews concerning presence and fate of this mycotoxin in grapes, wine and beer were published by Mateo et al. (2007) and Varga and Kozakiewicz (2006). Although the decrease of OTA content in liquid phase during vinification process is observed by the majority of researchers, reports are controversial regarding the mechanism of OTA removal. Is it a result of malolactic fermentation due to the action of lactic acid bacteria (Kozakiewicz et al., 2003), or is it adsorption to yeast cell walls (Binder et al., 2000). Reports about the capacity of proteolytic enzymes to hydrolyze OTA can also be found.

Furthermore, although the results of these studies look very promising for reducing OTA contamination, studies on model systems do not guarantee the degradation of OTA in situ, 
using food or feed. Further studies are needed to characterize the products of degradation and to investigate the activity of these bacteria in food and feedstuffs.

Patulin contamination of apple and other fruit-based foods and beverages is an important food safety issue due to the high consumption of these commodities. Patulin contamination is considered of greatest concern in apples and apple products; however, this mycotoxin has also been found in other fruits, such as pears, peaches, strawberries, blueberries, cherries, apricots and grapes as well as in cheese (Halász et al., 2009). The initial studies concerning degradation of patulin by actively fermenting yeasts were reported in the 1979 by Stinson et al. (1979). However, authors were not able to chemically characterize the products of degradation. More recently, Moss and Long (2002) reported that under fermentative conditions, the commercial yeast Saccharomyces cerevisiae transformed patulin into ascladiol.

In a recent study (Richelli et al., 2007) the ability of Gluconobacter oxydans to degrade patulin was investigated and the degradation products of this mycotoxin determined. More than $96 \%$ of patulin was degraded after twelve-hour treatment, due to change of chemical structure (opening of the pyran ring). The degradation product was confirmed to be ascladiol. The genus Gluconobacter, whose taxonomy is at present under worldwide study, is made up of five different species (Tanasupawat et al., 2004; Sievers et al., 1995) which have no health risk, and that are commonly used in food manufacturing. Apple juice inoculated with this bacterium and incubated for 3 days still tasted like juice and was drinkable. However, keeping in mind the toxicity of ascladiol and eventual unsatisfactory organoleptic properties of alcoholic apple (fruit) juice (apple wine), the use of this bacterium at the industrial level needs additional investigation.

In screenings for patulin detoxifying bacteria, has been isolated a bacterium from fermented sausage; it was identified as Lactobacillus plantarum, and it significantly reduced patulin levels via an intracellular enzyme (Halász et al., 2009).

Fusarium toxins Considerable amounts of the Fusarium mycotoxins zearalenone (ZEN) and its derivative a-zearalenol, were bound in vitro to the probiotic bacteria L. rhamnosus GG and L. rhamnosus LC705. Both heat-treated and acid-treated bacteria were capable of removing the toxins, indicating that binding, not metabolism is the mechanism by which the toxins are removed from the media (El-Nezami et al., 2002). Zearalenone was also degraded by a mixed bacterial culture. A few other microbial activities that transform zearalenone have been published but are protected by patents. Several micro-organisms have been found that can degrade DON and T-2. On the basis of morphological and phylogenetic studies, the degrader strain was classified as a bacterium belonging to the Agrobacterium Rhizobium group. Interactions between lactic strains and $\mathrm{ZEN}$ and its derivative, $\beta$-zearalenol were also investigated.

DON levels did not change during beer malting and the amount of trichothecene did not change during wine alcoholic fermentation. In contrast, trichothecene and iso-trichothecin were decomposed during alcoholic fermentation of grape juice. It was suggested that the yeast epihydroxylase might be involved.

A significant proportion (38-48\%) of both toxins was trapped in the bacterial pellet and no degradation product of zearalenone or a-zearalenol was detected (El-Nezami et al., 2002), leading to the conclusion that binding and not metabolism was the mechanism by which the 
toxins were removed from the media. Similar results were obtained with other mycotoxins including ochratoxin A (Del Prete et al., 2007; Fuchs et al., 2008) and fumonisin $B_{1}$ and $B_{2}$ (Niderkorn et al., 2006).

Therefore, two specific processes such as binding and inhibition of biosynthesis may be involved in the interaction between LAB and the accumulation of some mycotoxins.

Concerning the mechanisms of action involved in the removal of fumonisins by LAB, Niderkorn (2007) suggested that peptidoglycans were the most plausible fumonisin binding sites. The quenching ability of LAB was increased when bacteria were killed using different physical and chemical treatments, while lysozyme and mutanolysin enzymes that target peptidoglycans partially inhibited it. It was also reported that tricarballylic acid chains found in fumonisin molecules played an important role in the binding process since hydrolysed fumonisin had less affinity for LAB, and free amine group inactivation had no effect on the binding process (Niderkorn, 2007). The same article attempted to explain the low affinity of fumonisin $\mathrm{B}_{1}$ using a molecular modelling approach. In fact, an additional hydroxyl group in fumonisin $B_{1}$ could form a hydrogen bond with one of the tricarballylic acid chains, resulting in a spatial configuration where the tricarballylic acid chain is less available to interact with bacterial peptodoglycans.

Removal of fumonisins by LAB was ascribed to adhesion to cell wall components rather than covalent binding or metabolism, since the dead cells fully retained their binding ability. Peptidoglycans probably play a key rule in this binding process. Therefore, elucidating the differences between bacterial cell wall components of LAB strains might make it possible to select LAB species with the potential to act as biopreservative agents capable of reducing exposure from fumonisins that occur in food and feed.

\section{Conclusions}

The use of bacteriocins and/or bacteriocin-producing strains of LAB are of great interest as they are generally recognized as safe organisms and their antimicrobial products as biopreservatives. Several studies confirmed that microorganisms and enzymes could be a practical way to reduce the concentrations of some contaminants and to avoid the toxic effects via bioremediation. This opens up wide possibilities of using such biotechnological means on an food industry scale. Further experiments like utilization of the strains in fermentation processes or using the enzyme preprations can exhibit great outcomes. Great source of BLIS producing LAB strains could be traditional fermentation processes which should be more widely distributed as novel microorganisms crossing the borders. Further development of these strains for the biopreservation of food products requires an understanding of the mechanisms of action of the antimicrobial activity and of the decontamination of certain contaminants e.g. biogenic amines and mycotoxins. It seems that, according to results of the experiments to date, microorganisms are the main living organisms applicable for the biodegradation of these contaminants. Progress in this field of molecular biology techniques, antimicrobial LAB strains with multi-functional properties, including the degradation of mycotoxins, can be engineered to significantly improve the quality, safety and acceptability of plant foods. Further studies and knowledge of enzymes taking part in mycotoxin degradation allows production of these enzymes and their use for detoxification instead of microorganisms or additionally with LAB strains. Despite the 
intensive research in this field and of the numerous publications that confirm the ability of various microorganisms to degrade mycotoxins, lack of results achieved until now in the development of practical commercial technologies by using BLIS producing strains hampered progress. The majority of experiments were carried out in model systems and in laboratory conditions. The control of degradation products and the effects of detoxification on nutritive and sensory properties is in every case a decisive part of research and potential application. The use of antifungal LAB instead of chemical preservatives would enable the food industry to meet the request of consumers for natural products. Finally a practical technology should be developed and controlled from an economical point of view. Several studies confirmed that different environmental factors have strongly affected on the growth and bacteriocin production of several LAB strains that are mainly considered for food applications. However, it is desirable to continue the studies on this subject to select the most efficient factors and their combinations, which could be used on a production scale. Future work on LAB bacteriocin production, purification, obtaining the amino acid sequences of the BLIS to increase their activity is required.

\section{References}

Abrunhosa, L., Paterson, R.R.M., Venâncio, A. 2010. Biodegradation of ochratoxin A for food and Feed Decontamination. Toxins 2, 1078-1099.

Ancin-Azpilicueta, C., Gonzalez-Marco, A., Jimenez-Mareno, N. 2008. Current knowledge about the precense of biogenic amines in wine. Critical Reviews in Food Science and Nutrition 48, 257-275.

ANVISA - Brazilian Agency of Sanitary Surveillance. Food with health claims, new foods/ ingredients, bioactive compounds and probiotics.

http://www.anvisa.gov.br/alimentos/comissoes/tecno_lista_alega.htm. Accessed May 28, 2010.

Axelsson, L. Katla, T., Bjornslett, M., Vincent, Eijsink, G.H., Holck, A. 1988. A system for heterologous expression of bacteriocins in Lactobacillus sakei. FEMS Microbiology Letters 168 (1), 137-143.

Bailey, C.P., Von Holy, A. 1993. Bacillus spore contamination associated with commercial bread manufacture. Food Microbiology 10 (4), 287-294.

Batish, V.K., Grover, S., Lal, R. 1989. Screening lactic starter cultures for antifungal activity. Cultured Dairy Products Journal 24, 21-25.

Castellano, P., Farías, M.E., Holzapfel, W., Vignolo, G. 2001. Sensitivity variations of Listeria strains to the bacteriocins, lactocin 705, enterocin CRL35 and nisin. Biotechnology Letters 23 (8), 605-608.

Chassy, B.M. 2010. Food safety risk and consumer health. New Biotechnology 27 (5), 534-544.

Cintas, L.M., Casaus, M.P., Herranz, C., Nes, I.F., Hernández, P.E. 2001. Review: Bacteriocins of lactic acid bacteria. Food Science and Techology International 7 (4), 281-305.

Clarke, C.I., Schober, T.J., Dockery, P., O'Sullivan, K., Arendt, E.K. 2004. Wheat sourdough fermentation: effects of time and acidification on fundamental rheological properties. Cereal Chemistry 81 (3), 409-417.

Coallier-Ascah, J., Idziak E., 1985. Interaction between Streptococcus lactis and Aspergillus flavus on production of aflatoxin. Applied and Environmental Microbiology 49, $163-$ 167. 
Collins, N.E., Kirschner, L.M., Von Holy, A. 1991. Characterization of Bacillus isolates from ropey bread, bakery equipment and raw materials. South African Journal of Science 87, 62-66.

Condón, S. Palop, A., Raso, J., Sala, F.J. 1996. Influence of the incubation temperature after heat treatment upon the estimated heat resistance values of spores of Bacillus subtilis. Letters in Applied Microbiology 22 (2), 149-152.

Constantini, A., Cersosimo, M., Del Prete, V., Garcia-Moruno, E. 2006. Production biogenic amines by lactic acid bacteria: screening by PSR, thin chromatography and highperformance liquid chromatography of strains isolated from wine and must. Journal of Food Protection 69, 391-396.

Corsetti, A. De Angelis, M,, Dellaglio, F., Paparella, A., Fox, P.F., Settanni, L., Gobbetti, M. 2003. Characterization of sourdough lactic acid bacteria based on genotypic and cell-wall protein analyses. Journal of Applied Microbiology 94 (4), 641-654.

Corsetti, A., Settanni, L., Van Sinderen, D. 2004. Characterization of bacteriocin-like inhibitory substances (BLIS) from sourdough lactic acid bacteria and evaluation of their in vitro and in situ activity. Journal of Applied Microbiology 96 (3), 521-534.

Costantini, A., Vaudano, E., Prete, W.D., Danei, M., Garcia-Maruno, E., 2009. Biogenic amine production by contaminating bacteria found in starter preparations used in winemaking. Journal of Agricultura and Food Chemistry 57, 10664-10669.

Cotter, P.D., Hill, C., Ross, R.P. 2005. Bacteriocins: developing innate immunity for food. Nature Reviews Microbiology 3 (10), 777-788.

Cruz, A.G., Antunes, A.E.C., Sousa, A.L.O.P., Faria, J.A.F., Saad, S.M.I. 2009. Ice-cream as a probiotic food carrier. Food Research International 42, 1233-1239.

Cuozzo, S.A., Sesma, F., Palacios, J.M., de Ruíz Holgado, A.P., Raya, R.R. 2000. Identification and nucleotide sequence of genes involved in the synthesis of lactocin 705, a twopeptide bacteriocin from Lactobacillus casei CRL 705. FEMS Microbiology Letters 185 (2), 157-161.

Bartkiene, E., Juodeikiene, G., Vidmantiene, D., Viskelis, P., Urbonaviciene, D. 2011. Nutritional and quality aspects of wheat sourdough bread using L. luteus and L. angustifolius flours fermented by Pedioccocus acidilactici. International Journal of Food Science and Technology 46, 1724-1733.

Bartkiene, E., Juodeikiene, G., Vidmantiene, D. 2008. Evaluation of deoxynivalenol in wheat by acoustic method and impact of starter on its concentration during wheat bread baking process. Food Chemistry and Technology 42 (1), 5-12.

Binder, E.M, Heidler, D., Schatzmayr, G., Thimm, N., Fuchs, E., Schuh, M., Krska, R., Binder, J. 2000. Microbial detoxification of mycotoxins in animal feed. In Mycotoxins and Phytotoxins in Perspective at the Turn of the Millenium. Proceedings of the 10-th International IUPAC Symposium on Mycotoxins and Phytotoxins; De Koe, W.J., Samson, R.A., Van Egmond, H.P., Gilbert, J., Sabino, M., Eds; Garuja, Brazil, May 20-25, IUPAC, 271-277.

Bouchereau, A., Guenot, P., Larher, F. 2000. Analysis of amines in plant materials. Journal of Chromatography B 747, 49-67.

Bodmer, S., Imark, C., Kneubühl, M. 1999. Biogenic amines in foods: histamine and food processing. Inflammation Research 48, 296-300. 
Bogovic-Matijasic, B., Rogelj, I. 1998. Bacteriocin complex of Lactobacillus acidophilus LF221 production studies in MRS-media at different $\mathrm{pH}$-values and effect against Lactobacillus helveticus ATCC 15009. Process Biochemistry 33, 345-352.

Bogovič-Matijašić, B. Rogelj, I,, Nes, I.F., Holo, H. 1998. Isolation and characterization of two bacteriocins of Lactobacillus acidophilus LF221. Applied Microbiology and Biotechnology 49 (5), 606-612.

Böhm, J., Grajewski, J., Asperger, H., Rabus, B., Razzazi, E. 2000. Study on biodegradation of some trichothecenes (NIV, DON, DAS, T-2) and ochratoxin A by use of probiotic microorganisms. Mycological Research 16, 70-74.

Ciegler, A., Lillehoj, B., Peterson, H.H. 1966. Microbial detoxification of aflatoxin. Journal of Applied Microbiology 14, 934-939.

Dalié, D.K.D., Deschamps, A.M., Richard-Forget, F., 2009. A review: Lactic acid bacteria Potential for control of mould growth and mycotoxins. Food Control 21 (4), 370-380.

De Las Rivas, B., Marcobal, A., Muñoz, R. 2005. Improvedmultiplex-PCR method for the simultaneous detection of foodbacteria producing biogenic amines. FEMS Microbiology Letters 244, 367-372.

Delgado, A., Brito, D., Peres, C., Arroyo-L'opez, F.N., Garrido-Fern'andez, A. 2005. Bacteriocin production by Lactobacillus pentosus B96 can be expressed as a function of temperature and $\mathrm{NaCl}$ concentration. Food Microbiology 22, 521-528.

Delgado, A., Arroyo-L'opez, N.F., Brito D., Peres, C., Fevereiro, P., Garrido-Fern'andez, A. 2007. Optimum bacteriocin production by Lactobacillus plantarum $17.2 \mathrm{~b}$ requires absence of $\mathrm{NaCl}$ and apparently follows a mixed metabolite kinetics. Journal of Biotechnology 130, 193-201.

Delves-Broughton, J. 1990. Nisin and its uses as a food preservative. Food Technology 44, 100117.

Deraz, S.F. Karlsson, E.N., Khalil, A.A., Mattiasson, B. 2007. Mode of action of acidocin D20079, a bacteriocin produced by the potential probiotic strain, Lactobacillus acidophilus DSM 20079. Journal of Industrial Microbiology and Biotechnology 34 (5), 373-379.

De Vuyst, L., Vancanneyt, M. 2007. Biodiversity and identification of sourdough lactic acid bacteria. Food Microbiology 24 (2), 120-127.

Del Prete, V., Rodriguez, H., Carrascosa, A.V., Rivas, B.D.L., Garcia-Moruno, E., Munoz, R. 2007. In vitro removal of ochratoxin A by wine lactic acid bacteria. Journal of Food Protection 70, 2155-2160.

Digaitiene, A., Hansen, Å., Juodeikiene, G., Josephsen, J. 2005. Microbial population in Lithuanian spontaneous rye sourdoughs. Ecology and Technology 5 (77), 193-198.

Driks, A. 2002. Overview: Development in bacteria: spore formation in Bacillus subtilis. Cellular and Molecular Life Sciences 59 (3), 389-391.

El-Nezami, H.S., Kankaanpää, P., Salminen, S., Ahokas, J. 1998a. Ability of dairy strains of lactic acid bacteria to bind a common food carcinogen, aflatoxin B1. Food and Chemical Toxicology 36, 321-326.

El-Nezami, H.S., Kankaanpää, P., Salminen S., Ahokas, J. 1998b. Physiochemical alterations enhance the ability of dairy strains of lactic acid bacteria to remove aflatoxin from contaminated media. Journal of Food Protection 61, 446-448. 
El-Nezami, H.S., Polychronaki, N., Salminen, S., Mykkänen H. 2002. Binding rather metabolism may explain the interaction of two food-grade Lactobacillus strains with zearalenone and its derivative a-zearalenol. Applied and Environmental Microbiology $68,3545-3549$.

Eichenberger, P., Fujita, M., Jensen, S.T., Conlon, E.M., Rudner, D.Z., Wang, S.T., Ferguson, C., Haga, K., Sato, T., Liu, J.S., Losick, R. 2004. The program of gene transcription for a single differentiating cell type during sporulation in Bacillus subtilis. Public Library of Science 2 (10), 328.

Eijsink, V.G., Axelsson, L., Diep, D.B., Håvarstein, L.S., Holo, H., Nes, I.F. 2002. Production of class II bacteriocins by lactic acid bacteria; an example of biological warfare and communication. Antonie Van Leeuwenhoek 81 (1-4), 639-654.

Ennahar, S., Aoude-Werner, D., Sorokine, O., Van Dorsselaer, A., Bringel, F., Hubert, J.C., Hasselmann, C. 1996. Production of pediocin AcH by Lactobacillus plantarum WHE 92 isolated from cheese. Applied and Environmental Microbiology 62 (12), 4381-4387.

Errington, J. 2003. Regulation of endospore formation in Bacillus subtilis. Nature Reviews Microbiology 1 (2), 117-126.

FAO-WHO 2002. Food and agriculture organization of the United Nations, World Health Organization. Report of a joint FAOWHO working group on drafting guidelines for the evaluation of probiotics in food. Ontario. ftp:/ /ftp.fao.org/docrep/fao/009/a0512e/a0512e00.pdf

Fernandez, M., Linares, D.M., Rodriguez, A., Alvarez, M.A. 2007. Factors affecting tyramine production in Enteroccus durans IPLA 655. Applied Microbiology and Biotechnology 73, 1400-1406.

Frisvad, J.C., Thrane, U., Samson, R.A., Pitt, J.I. 2006. Important mycotoxins and the fungi which produce them. Advances in Food Mycology 571, 3-31.

Fuchs, S., Sontag, G., Stidl, R., Ehrlich, V., Kundi, M., Knasmuller, S. 2008. Detoxification of patulin and ochratoxin A, two abundant mycotoxins, by lactic acid bacteria. Food and Chemical Toxicology 46, 1398-1407.

Gálvez, A., Valdivia, E., Martínez-Bueno, M., Maqueda, M. 1990. Induction of autolysis in Enterococcus faecalis S-47 by peptide AS-48. Journal of Applied Bacteriology 69, 406413.

Galvez, A., Lopez, R.L., Abriouel, H. 2008. Application of bacteriocins in the control of foodborne pathogenic and spoilage bacteria. Critical Reviews in Biotechnology 28, 125-152.

Gänzle, M.G. 1998. Useful Properties of Lactobacilli for application as protective cultures in food. PhD thesis. University of Hohenheim, Germany.

Garcia-Ruiz, A., Gonzalez-Rompinelli, E.M., Bartolome, B., Moreno-Arribas, M.V. 2011. Potential of wine-associated lactic acid bacteria to degrade biogenic amines. International Journal of Microbiology 148, 115-120.

Gillor, O., Etzion, A., Riley, M.A. 2008. The dual role of bacteriocins as anti- and probiotics. Applied Microbiology and Biotechnology 81 (4), 591-606.

Gobbetti, M. et al. 2005. Biochemistry and physiology of sourdough lactic acid bacteria. Trends in Food Science and Technology 16 (1-3), 57-69.

Gonzaga, V.E., Lescano, A.G., Huaman, A.A., Salmon-Mulanovich, G., Blazes, D.I. 2009. Histamine levels in fish from markets in Lima, Peru. Journal of Food Protection 72, 1112-1115. 
Gourama, H. 1997a. Inhibition of growth and mycotoxin production of Penicillium by Lactobacillus species. Lebensmittel- Wissenschaft und-Technologie 30, 279-283.

Gourama, H., Bullerman, L.B. 1997b. Anti-aflatoxigenic activity of Lactobacillus casei pseudoplantarum. International Journal of Food Microbiology 34, 131-143.

Gourama, H., Bullerman, L.B. 1995. Inhibition of growth and aflatoxin production of Aspergillus flavus by Lactobacillus species. Journal of Food Protection 58, 1249-1256.

Gourama, H. 1991. Growth and aflatoxin production of Aspergillus flavus in the presence Lactobacillus species. Ph.D. thesis, University of Nebraska-Lincoln.

Gratz, S., Mykkänen, H., Ouwehand, A.C, Juvonen, R., Salminen S., El-Nezami H.S. 2004. Intestinal mucus alters the ability of probiotic bacteria to bind aflatoxin B1 in vitro. Applied and Environmental Microbiology 70, 6306-6308.

Grossman, A.D., Losick, R. 1988. Extracellular control of spore formation in Bacillus subtilis. Proceedings of the National Academy of Sciences 85 (12), 4369-4373.

Harlander, S.K. 1993. Bacteriocins of Lactic Acid Bacteria, Academic Press, San Diego, CA, pp. 233-247.

Halász, A., Lásztity, R., Abonyi, T., Bata, A. 2009. Decontamination of mycotoxin-containing food and feed by biodegradation. Food Reviews International 25, 284-298.

Hammes, W.P., Gänzle, M.G. 1998. Sourdough breads and related products. In Wood, B.J.B. Eds. Microbiology of Fermented Foods (Volume 1). London: Chapman \& Hall, UK., pp. 199- 216.

Hansen, Å.S. 2004. Sourdough bread. In Hui et al. Eds., Handbook of Food and Beverage Fermentation Technology, Marcel Dekker Inc., Florida, USA, pp. 729-755.

Harris, L.J. Daeschel, M.A., Stiles, M.E, Klaenhammer, T.R. 1989. Antimicrobial activity of lactic acid bacteria against Listeria monocytogenes. Journal of Food Protection 52 (6), 384-387.

Haskard, C.A., El-Nezami, H.S., Peltonen, K.D., Salminen, S., Ahokas, J.T. 1998. Sequestration of aflatoxin $B_{1}$ by probiotic strains: Binding capacity and localization. Revue de Medecine Veterinaire 149, 571.

Haskard, C.A., Binnion, C., Ahokas, J. 2000. Factors affecting the sequestration of aflatoxin by Lactobacillus rhamnosus strain GG. Chemico-Biological Interactions 128, 39-49.

Haskard, C.A., El-Nezami, H.S., Kankaanpää, P.E., Salminen, S., Ahokas, J.T. 2001. Surface binding of aflatoxin $\mathrm{B}_{1}$ by lactic acid bacteria. Applied and Environmental Microbiology 67, 3086-3091.

Hassan, Y.I., Bullerman, L.B. 2008. Antifungal activity of Lactobacillus paracasei ssp. tolerans isolated from a sourdough bread culture. International Journal of Food Microbiology 121 (1), 112-115.

He, J., Zhou, T., Young, J.C., Boland, G.J., Scott, P.M. 2010. Chemical and biological transformations for detoxification of trichothecene mycotoxins in human and animal food chains: a review. Trends in Food Science \& Technology 21 (2), 67-76.

Heng, N.C.K., Wescombe, P.A., Burton, J.P., Jack, R.W., Tagg, J.R. 2007. The Diversity of bacteriocins in Gram-positive bacteria. In Riley, M.A., Chavan, M., Eds., Bacteriocins: ecology and evolution. Springer Berlin Heidelberg, New York, USA, pp. 45-93. 
Hernandez-Jover, T., Izquierdo-Pulido, M., Veciana-Nogues, M.T., Marine-Font, A., VidalCarou, M.C. 1997. Biogenic amines and polyamine contents in meat and meat products. Journal of Agricultural Food Chemistry 45, 2098-2102.

Holzapfel, W.H., Geisen, R., Schillinger, U. 1995. Biological preservation of foods with reference to protective cultures, bacteriocins and food-grade enzymes. International Journal of Food Microbiology 24, 343-362.

Hoover, D.G., Chen, H. 2005. Bacteriocins with potential for use in foods. In Davidson, P.M., Sofos, J.N., Branen, A.L. Eds., Antimicrobials in Food (3rd edition). Taylor \& Francis Group, LLC, FL, USA, pp. 389-428.

Hoover, D.G., Dishart, K.J., Hermes, M.A. 1989. Antagonistic effect of Pediococcus spp. against Listeria monocytogenes. Food Biotechnology 3 (2), 183-196.

Hugas, M. Pagés, F., Garriga, M., Monfort, J.M. 1998. Application of the bacteriogenic Lactobacillus sakei CTC494 to prevent growth of Listeria in fresh and cooked meat products packed with different atmospheres. Food Microbiology 15 (6), 639-650.

Hughes, M.C., Kerry, J.P., Arendt, E.K., Kenneally, P.M., McSweeney, P.L.H., O'Neill, E.E. 2002. Characterization of proteolysis during the ripening of semi-dry fermented sausages. Meat Science 62, 205-216.

Jack, R.W., Tagg, J.R., Ray, B. 1995. Bacteriocins of Gram-positive bacteria. Microbiological Reviews 59, 171-200.

Jiménez-Díaz, R., Rios-Sanchez, R.M., Desmazeaud, M., Ruiz-Barba, J.L., Piard, J.C. 1993. Plantaricin $S$ and $T$, two new bacteriocins produced by Lactobacillus plantarum LPCO10 isolated from a green olive fermentation. Applied and Environmental Microbiology 59, 1416-1424.

Johnsen, L. Fimland, G., Eijsink, V., Nissen-Meyer, J. 2000. Engineering increased stability in the antimicrobial peptide pediocin PA-1. Applied and Environmental Microbiology 66 (11), 4798-4802.

Joshi, V.K., Sharma, S., Ranaet, N.S. 2006. Bacteriocin from lactic acid fermented vegetables. Food Technology and Biotechnology 44 (3), 435-439.

Juodeikiene, G., Salomskiene, J., Eidukonyte, D., Vidmantiene, D., Narbutaite, V., Vaiciulyte-Funk, L. Impact of novel fermented products on the base of extruded wheat material on the quality of wheat bread, Food Technology and Biotechnology, 2011 (Article in Press).

Juodeikiene, G., Basinskiene, L., Vidmantiene, D., Makaravicius, T., Bartkiene, E. Benefits of $\beta$-xylanase for wheat biomass conversion to bioethanol. Journal of the Science of Food and Agriculture, 2011 Jul 11. (Article in Press).

Ladero, V., Calles- Enríquez, M., Fernández, M., Alvarez, M.A. 2010. Toxicological effects of dietary biogenic amines. Current Nutrition and Food Science 6, 145-156.

Larsen, A.G., Nørrung, B. 1993. Inhibition of Listeria monocytogenes by bavaricin A, a bacteriocin produced by Lactobacillus bavaricus MI401. Letters in Applied Microbiology 17 (3), 132- 134.

Leal-Sánchez, M.V., Jiménez-Díaz, R., Maldonado- Barragán, A., Garrido-Fernández, A., Ruiz-Barba, J.L., 2002. Optimization of bacteriocin production by batch fermentation of Lactobacillus plantarum LPCO10. Applied and Environmental Microbiology 68, 4465-4471. 
Leal, M.V., Baras, M., Ruiz-Barba, J.L., Floriano, B., Jiménez-Díaz, R. 1998. Bacteriocin production and competitiveness of Lactobacillus plantarum LPCO10 in olive juice broth, a culture medium obtained from olives. International Journal of Food Microbiology 43, 129-134.

Leer, R.J., Van der Vossen, J.M.B.M., Van Giezen, M., Van Noort Johannes, M., Pouwels, P.H. 1995. Genetic analysis of acidocin B, a novel bacteriocin produced by Lactobacillus acidophilus. Microbiology 141 (7), 1629-1635.

Leroy, F., Verluyten, J., Messens, W., De Vuyst, L. 2002. Modeling contributes to the understanding of the different behaviour of bacteriocin-producing strains in a meat environment. International Dairy Journal 12, 247-253.

Leuschner, R.S., Heidel, M., Hammes, W.P. 1998. Histamine and tyramine degradation by food fermenting microorganisms. International Journal of Food Microbiology 39, 1-10.

Luchese, R.H., Harrigan, W.F. 1990. Growth of and aflatoxin production by Aspergillus parasiticus when in the presence of either Lactococcus lactis or lactic acid and at different initial $\mathrm{pH}$ values. Journal of Applied Bacteriology 69, 512-519.

Lucas, P.M., Gaisse, O., Lonvaud-Funel, A. 2008. High frequency of histamine producing bacteria in the enological environment and instability of the histidine decarboxylase production phenotype. Applied and Environmental Microbiology 74, 811-817.

Kalač, P., Šavel, J., Križek, M., Pelikánová, T., Prokopová, M. 2002. Biogenic amine formation in bottled beer. Food Chemistry 79, 431-434.

Kalač, P., Švecova, S., Pelikánová, T. 2002. Levels of biogenic amines in typical vegetable products. Food Chemistry 77, 349-351.

Kankaanpää, P., Tuomola, E., El-Nezami, H., Ahokas, J., Salminen, S.J. 2000. Binding of aflatoxin B1 alters the adhesion properties of Lactobacillus rhamnosus strain GG in Caco-2 model. Journal of Food Protection 63, 412-414.

Katina, K., Arendt, E., Liukkonen, K. H., Autio, K., Flander, L., Poutanen, K. 2005. Potential of sourdough for healthier cereal products. Trends in Food Science and Technology 16, 104-112.

Katina, K., Sauri, M., Alakomi, H.L., Mattila-Sandholm, T. 2002. Potential of lactic acid bacteria to inhibit rope spoilage in wheat sourdough bread. LebensmittelWissenschaft und-Technologie 35 (1), 38-45.

Karunaratne, A., Wezenberg, E., Bullerman, L.B. 1990. Inhibition of mold growth and aflatoxin production by Lactobacillus spp. Journal of Food Protection 53, 230-236.

Kim, W.S., Hall, R.J., Dunn, N.W. 1997. The effect of nisin concentration and nutrient depletion on nisin production of Lactococcus lactis. Applied Microbiology and Biotechnology 50, 429- 433.

Kingamkono, R., Sjögren, E., Svanberg, U., Kaijser, B. 1994. pH and acidity in lacticfermenting cereal gruels - effects on viability of enteropathogenic microorganisms. World Journal of Microbiology and Biotechnology 10, (6), 664-669.

Kirschbaum, J., Rebscher, K., Bruckner, H. 2000. Liquid chromatographic determination of biogenic amines in fermented foods after derivatization with 3,5-dinitrobenzoyl chloride. Journal of Chromatography A 881, 517-530.

Klaenhammer, T.R. 1993. Genetics of bacteriocins produced by lactic acid bacteria. FEMS Microbiology Reviews 12, 39-86. 
Kozakiewicz, Z., Battilani, P., Cabanes, I., Venancio, A., Mule, G., Tjamos, E. Making wine safer. In Meeting the Mycotoxin Menace, van Egmond, H., van Osenbruggen, T., Lopez Garcia, R., Visconti, A., Eds., Wageningen Academic Publisher: Wageningen, 2003 pp.131-140.

Kramer, J., Gilbert, R. Bacillus cereus and other Bacillus sp. In Doyle, M.P., Eds., Foodborne Bacterial Pathogens. Marcel Dekker Inc., New York, USA, 1989, pp. 22-70.

Kunst, F. et al. 1997. The complete genome sequence of the Gram-positive bacterium Bacillus subtilis. Nature 390 (6657), 249-256.

Mao, Y., Muriana, P.M., Cousin, M.A. 2001. Purification and transpositional inactivation of lacticin FS92, a broad-spectrum bacteriocin produced by Lactococcus lactis FS92. Food Microbiology 18 (2), 165-175.

Marín, S., Guynot, M.E., Neira, P., Bernadó, M., Sanchis, V., Ramos, A.J. 2002. Risk assessment of the use of sub-optimal levels of weak-acid preservatives in the control of mould growth on bakery products. International Journal of Food Microbiology 79 (3), 203-211.

Marugg, J.D., Gonzalez, C.F., Kunka, B.S. Ledeboer, A.M., Pucci, M.J., Toonen, M.Y., Walker, S.A., Zoetmulder, L.C., Vandenbergh, P.A. 1992. Cloning, expression, and nucleotide sequence of genes involved in production of pediocin PA-1, and bacteriocin from Pediococcus acidilactici PAC1.0. Applied and Environmental Microbiology 58 (8), 2360-2367.

Martınez-Anaya, M.A. 1996. Enzymes and bread flavor. Journal of Agricultural and Food Chemistry 44, 2469-2480.

Martínez-Cuesta, M.C., Requena, T., Peláez, C. 2006. Cell membrane damage induced by lacticin 3147 enhances aldehyde formation in Lactococcus lactis IFPL730. International Journal of Food Microbiology 109 (3), 198-204.

Martinez, R.C.R., De Martinis, E.C.P. 2006. Effect of Leuconostoc mesenteroides 11 bacteriocin in the multiplication control of Listeria monocytogenes. Ciźnia e Tecnologia de Alimentos 26 (1), 52-55.

Mateo, R., Medina, A., Mateo, E.M., Mateo, F., Jimenez, M. 2007. An overview of ochratoxin $\mathrm{A}$ in beer and wine. International Journal of Food Microbiology 119 (1-2), 79-83.

Moreno-Aribas, M.V., Polo M.C. 2010.Wine Chemistry and Biochemistry. In Mycotoxins in food Detection and control: Biological decontamination of mycotoxins, Magan, N. and Olsen, M., Eds., Springer New York., Woodhead Publishing Ltd and CRC Press LLC, pp. 2006-211.

McKay, L.L., Baldwin, K.A. 1990. Application for biotechnology: present and future improvements in lactic acid bacteria. FEMS Microbiology reviews 7, 3-14.

McAuliffe, O., Hill, C., Ross, R.P. 1999. Inhibition of Listeria monocytogenes in cottage cheese manufactured with a lacticin 3147-producing starter culture. Journal of Applied Microbiology 86 (2), 251-256.

Mendoza, F., Maqueda, M., Gálvez, A., Martínez-Bueno, M., Valdivia, E. 1999. Antilisterial activity of peptide AS-48 and study of changes induced in the cell envelope properties of an AS-48-adapted strain of Listeria monocytogenes. Applied and Environmental Microbiology 65, 618-625. 
Mentes, Ö., Ercan, R., Akçelik, M. 2007. Inhibitor activities of two Lactobacillus strains, isolated from sourdough, against rope-forming Bacillus strains. Food Control 18 (4), 359-363.

Messens,W., De Vuyst, L. 2002. Inhibitory substances produced by lactobacilli isolated from sourdoughs - a review. International Journal of Food Microbiology 72, 31-43.

Messens, W., Neysens, P., Vansieleghem, W., Vanderhoeven, J., De Vuyst, L. 2002. Modeling growth and bacteriocin production by Lactobacillus amylovorus DCE 471 in response to temperature and $\mathrm{pH}$ values used for sourdough fermentations. Applied and Environmental Microbiology 68 (3), 1431-1435.

Miller, K.W., Schamber, R., Osmanagaoglu, O., Ray, B. 1998. Isolation and characterization of pediocin AcH chimeric protein mutants with altered bactericidal activity. Applied and Environmental Microbiology 64 (6), 1997-2005.

Minei, C.C., Gomes, B.C., Ratti, R.P., D'Angelis, C.E.M., De Martinis, E.C.P. 2008. Influence of peroxyacetic acid and nisin and coculture with Enterococcus faecium on Listeria monocytogenes biofilm formation. Journal of Food Protection 71, 634-638.

Morency, H., Mota-Meira, M., LaPointe, G., Lacroix, C., Lavoie, M.C. 2001. Comparison of the activity spectra against pathogens of bacterial strains producing a mutacin or a lantibiotic. Canadian Journal of Microbiology 47 (4), 322-331.

Moreno, I., Lerayer, A.L.S., Baldini, V.L.S., Leitao, M.F.F. 2000. Characterization of bacteriocins produced by Lactococcus lactis strains. Brazilian Journal of Microbiology 31, 184-192.

Moret, S., Smela, D., Populin, T., Conte, L.S. 2005. A survey on free biogenic amine content of fresh and preserved vegetables. Food Chemistry 89, 355-361.

Moretro, T., Aassen, I.M., Storro, I., Axelsson, L. 2000. Production of sakacin P by Lactobacillus sakei in a completely defined medium. Journal of Applied Microbiology 88, 536-545.

Mørtvedt, C.I., Nes, I.F. 1990. Plasmid-associated bacteriocin production by a Lactobacillus sake strain. Journal of General Microbiology 136 (8), 1601-1607.

Moss, M.O., Long, M.T. 2002. Fate of patulin in the presence of the yeast Saccharomyces cerevisiae. Food Additives \& Contaminants 19, 387-399.

Mota-Meira, M., Morency, H., Lavoie, M.C. 2005. In vivo activity of mutacin B-Ny266. Journal of Antimicrobial Chemotherapy 56 (5), 869-871.

Mower, H. F., Bhagavan, N.V. 1989. Tyramine content of Asian and Pacific foods determined by high performance liquid chromatography. Food Chemistry 31, 251257.

Narbutaite, V., Fernandez, A., Horn, N., Juodeikiene, G., Narbad, A. 2008. Influence of baking enzymes on antimicrobial activity of five bacteriocin-like inhibitory substances produced by lactic acid bacteria isolated from Lithuanian sourdoughs. Letters in Applied Microbiology 47 (6), 555-560.

Nes, I. F., Holo, H. 2000. Class II antimicrobial peptides from lactic acid bacteria. Biopolymers 55 (1), 50-61.

Nes, I. F., Diep, D.B., Håvarstein, L.S., Brurberg, M.B., Eijsink, V., Holo, H. 1996. Biosynthesis of bacteriocins in lactic acid bacteria. Antonie Leeuwenhoek 70, 113-128.

Neysen, P., De Vuyst, L. 2005. Kinetic and modeling of sourdough lactic bacteria. Trends in Food Science \& Technology 16, 95-103. 
Niderkorn, V., Boudra, H., Morgavi, D.P. 2006. Binding of Fusarium mycotoxins by fermentative bacteria in vitro. Applied and Environmental Microbiology 101, 849-856.

Niderkorn, V. 2007. Activites de biotransformation et de séquestration des fusariotoxines chez les bactéries fermentaires pour la détoxification des ensilages de maïs. $P h D$ thesis, Blaise Pascal University, France.

Oppegård, C., Fimland, G., Thorbæk, L., Nissen-Meyer, J. 2007. Analysis of the two-peptide bacteriocins Lactococcin G and Enterocin 1071 by site-directed mutagenesis. Applied and Environmental Microbiology 73 (9), 2931-2938.

Östman, E.M., Nilsson, M., Elmstahl, H., Molin, G., Bjorck, I. 2002. On the effect of lactic acid on blood glucose and insulin responses to cereal products: mechanistic studies in healthy subjects and in vitro. Journal of Cereal Science 36 (3), 339-346.

Parada, J.L., Caron, C.R., Bianchi, A., Medeiros, P., Soccol, C. R. 2007. Bacteriocins from lactic acid bacteria: purification, properties and use as biopreservatives. Brazilian Archives of Biology and Technology 50, 521-542.

Patharajan, S., Reddy, K.R.N., Karthikeyan, V., Spadaro, D., Lore, A., Gullino, M.L., Garibaldi, A. 2011. Potential of yeast antagonists on invitro biodegradation of ochratoxin A. Food Control 22, 290-296.

Pattison, T.L., Lindsay, D., von Holy, A. 2004. Natural antimicrobials as potential replacements for calcium propionate in bread. South African Journal of Science 100 (7-8), 342-348.

Pepe, O., Blaiotta, G., Moschetti, G., Greco, T., Villani, F. 2003. Rope-producing strains of Bacillus spp. from wheat bread and strategy for their control by lactic acid bacteria. Applied and Environmental Microbiology 69 (4), 2321-2329.

Piggot, P.J., Hilbert, D.W. 2004. Sporulation of Bacillus subtilis. Current Opinion in Microbiology 7 (6), 579-586.

Piotrowska, M., Zakowska, Z. 2000. The biodegradation of ochratoxin A in food products by lactic acid bacteria and baker's yeast. In Progress in Biotechnology (Food Biotechnology); Bielecki, S., Tramper, J., Polak, J., Eds., Elsevier, Amsterdam, The Netherlands, Volume 17, pp. 307-310.

Piotrowska, M., Zakowska, Z. 2005. The elimination of ochratoxin A by lactic acid bacteria strains. Polish Journal of Microbiology 54, 279-286.

Phillips, Z.E., Strauch, M.A. 2002. Bacillus subtilis sporulation and stationary phase gene expression. Cellular and Molecular Life Sciences 59 (3), 392-402.

Powell, J.E., Todorov, S.D., van Reenen, C.A., Dicks, L.M.T., Witthuhn, R.C. 2006. Growth inhibition of Enterococcus mundtii in Kefir by in situ production of bacteriocin ST8KF. Le Lait 86, 401-405.

Rasch, M., Knøchel, S. 1998. Variations in tolerance of Listeria monocytogenes to nisin, pediocin PA-1 and bavaricin A. Letters in Applied Microbiology 27 (5), 275-278.

Ravel, J., Fraser, C.M. 2005. Genomics at the genus scale. Trends in Microbiology 13 (3), 95-97.

Richelli, A., Baruzzi, F., Solfrizzo, M., Morea, M., Fanizzi, F.P. 2007. Biotransformation of patulin by Gluconobacter oxydans. Applied and Environmental Microbiology 73, 785792.

Riebroy, S., Benjakul, S., Visessanguan, W., Kijrongrojana, K., Tanaka, M. 2004. Some characteristics of commercial Som-fug produced in Thailand. Food Chemistry 88, 527-535. 
Röcken, W. 1996. Applied aspects of sourdough fermentation. Advances in Food Sciences 18 (5-6), 212-216.

Rogers, L.A. 1928. The inhibitory effect of Sreptococcus lactis on Lactobacillus bulgaricus. Journal of Bacteriology 16, 321-325.

Rosenkvist, H., Hansen, $\AA$. 1995. Contamination profiles and characterization of Bacillus species in wheat bread and raw materials for bread production. International Journal of Food Microbiology 26 (3), 353-363

Røssland, E., Andersen Borge, G.I., Langsrud, T., Sørhaug. T. 2003. Inhibition of Bacillus cereus by strains of Lactobacillus and Lactococcus in milk. International Journal of Food Microbiology 89 (2-3), 205-212.

Ross, R.P., Morgan, S., Hill, C. 2002. Preservation and fermentation: past, present and future. International Journal of Food Microbiology 79, 3-16.

Ross, R.P., Stanton, C., Hill, C., Fitzgerald, G.F., Coffey, A. 2000. Novel cultures for cheese improvement. Trends in Food Science and Technology 11 (3), 96-104.

Roy, U., Batish, V.K., Grover, S., Neelakantan, S. 1996. Production of antifungal substance by Lactococcus lactis subsp. lactis CHD-28.3. International Journal of Food Microbiology 32, 27-34.

Ryan, L.A.M., Dal Bello, F., Arendt, E.K. 2008. The use of sourdough fermented by antifungal $\mathrm{LAB}$ to reduce the amount of calcium propionate in bread. International Journal of Food Microbiology 125 (3), 274-278.

Saaid, M., Saad, B., Hashim, N.H., Ali, M.A.S., Saleh, M.I. 2009. Determination of biogenic amines in selected Malaysian food. Food Chemistry 113, 1356-1362.

Sahl, H.G., Bierbaum., G. 1998. Lantibiotics: biosynthesis and biological activities of uniquely modified peptides from Gram-positive bacteria. Revista de Microbiologia $52,41-79$.

Sadeghi, A. 2008. The secrets of sourdough: A review of miraculous potentials of sourdough in bread shelf life. Biotechnology 7 (3), 413-417.

Settani, L., Massitti, O., Van Sinderen, D., Corsetti, A. 2005. In situ activity of a bacteriocin producing Lactococcus lactis strain. Influence on the interactions between lactic acid bacteria during sourdough fermentation. Journal of Applied Microbiology 99, 670-681.

Schillinger, U., Lücke, F.K. 1989. Antibacterial activity of Lactobacillus sake isolated from meat. Applied and Environmental Microbiology 55 (8), 1901-1906.

Schleifer, K.H., Kraus, J., Dvorak, C., Kilpper-Bälz, R., Collins, M.D., Fischer, W. 1985. Transfer of Streptoccus lactis and related streptoccus to the genus of Lactococcus gen nov. Systematic and Applied Microbiology 6, 183-195.

Sievers, M., Garerth, I.C., Becsh, C., Ludwig, W., Teuber, M. 1995. Phylogenetic position of Gluconobacterspecies as a coherent cluster from all Acetobacter species on the basis of $16 S$ ribosomal RNA sequences. FEMS Microbiology Letters 126, 123-126.

Silla Santos, M.H. 1996. Biogenic amines: their importance in foods. International Journal of Food Microbiology 29, 213-231.

Silveira, T.F.V., Vianna, C.M.M., Mosegui, G.B.G. 2009. Brazilian legislation for functional foods and the interface with the legislation for other food and medicine classes: contradictions and omissions. Physis Revista de Saúde Coletiva 19, 1189-1202. 
Simova, E.D., Beshkova, D.B., Dimitrov, Z.P. 2009. Characterization and antimicrobial spectrum of bacteriocins produced by lactic acid bacteria isolated from traditional Bulgarian dairy products. Journal of Applied Microbiology 106 (2), 692-701.

Şimşek, Ö., Çon, A.H., Tulumoĝlu, Ş. 2006. Isolating lactic starter cultures with antimicrobial activity for sourdough processes. Food Control 17 (4), 263-270.

Shah, N., Wu, X. 1999. Aflatoxin $\mathrm{B}_{1}$ binding abilities of probiotic bacteria. Bioscience and Microflora 18, 43-48.

Shalaby, A.R. 1996. Significance of biogenic amines to food safety and human health. Food Research International 29, 675-690.

Shetty, P.H., Jespersen, L. 2006. Saccharomyces cerevisiae and lactic acid bacteria as potential mycotoxin decontaminating agents. Trends in Food Science \& Technology 17, 48-55.

Sorokulova, I.B., Reva, O.N., Smirnov, V.V., Pinchuk, I.V., Lapa, S.V., Urdaci, M.C. 2003. Genetic diversity and involvement in bread spoilage of Bacillus strains isolated from flour and ropy bread. Letters in Applied Microbiology 37 (2), 169-173.

Stinson, E.E., Osman, S.F., Bills, D.D. 2006. Water soluble products from patulin during alcoholic fermentation of apple juice. Journal of Food Science 44 (3), 788-789.

Stratton, J.E., Hutkins R.W., Taylor S.I. 1991. Biogenic amines in cheese and other fermented foods: a review. Journal of Food Protection 54, 460-470.

Stauffer, C.E. 1994. Enzymes used in bakery products. Fundamentals of enzymes. AIB Tech Bull XVI, 1-6.

Stiles, M.E. 1996. Biopreservation by lactic acid bacteria. Antonie van Leuwenhoek 70, 331-345.

Svanberg, U., Sjögren, E., Lorri, W., Svennerholm, A.M., Kaijser, B. 1992. Inhibited growth of common enteropathogenic bacteria in lactic-fermented cereal gruels. World Journal of Microbiology and Biotechnology 8 (6), 601-606.

Suomalainen, T.H., Mäyrä-Makinen, A.M. 1999. Propionic acid bacteria as protective cultures in fermented milks and breads. Lait 79 (1), 165-174.

Tanasupawat, S., Thawai, C., Yukphan, P., Moonmangmee, D., Itoh, T., Adachi, O., Yamada, Y. 2004. Gluconobacter thailandicus sp. nov., an acetic acid bacterium in the alpfaProteobacteria. The Journal of General and Applied Microbiology 50, 159-167.

Thomas, L.V., Clarkson, M.R., Delves-Broughton, J. In Natural food antimicrobial systems, Thomas, L.V., Clarkson, M.R. and Delves-Broughton, J., Eds., CRC Press, A.S. Naidu, USA, 2000, pp. 463-524.

Thomas, L.V., Delves-Broughton, J. 2001. New advances in the application of food preservative nisin. Recent Advances in Food Science 2, 11-22.

Thompson, J.M., Dodd, C.E.R., Waites, W.M. 1993. Spoilage of bread by Bacillus. International Biodeterioration \& Biodegradation 32 (1-3), 55-66.

Todorov, S., Gotcheva, B., Dousset, X., Onno, B., Ivanova, I. 2000. Influence of growth medium on bacteriocin production in Lactobacillus plantarum ST31. Biotechnology $\mathcal{E}$ Biotechnological Equipment 14, 50-55.

Todorov, S.D., Dicks, L.M.T. 2004. Effect of medium components on bacteriocin production by Lactobacillus pentosus ST151BR, a strain isolated from beer produced by the fermentation of maize, barley and soy flour. World Journal of Microbiology and Biotechnology 20, 643-650. 
Todorov, S.D., Van Reenen, C.A., Dicks, L.M.T. 2004. Optimization of bacteriocin production by Lactobacillus plantarum ST13BR, a strain isolated from barley beer. Journal of General and Applied Microbiology 50, 149-157.

Todorov, S.D., Dicks, L.M.T. 2004. Influence of growth conditions on the production of a bacteriocin by Lactococcus lactis subsp. lactis ST34BR, a strain isolated from barley beer. Journal of Basic Microbiology 44, 305-316.

Todorov, S.D., Dicks L.M.T. 2005a. Effect of growth medium on bacteriocin production by Lactobacillus plantarum ST194BZ, a strain isolated from boza. Food Technology and Biotechnology 43, 165-173.

Todorov, S.D., Dicks L.M.T. 2005b. Lactobacillus plantarum isolated from molasses produces bacteriocins active against Gram-negative bacteria. Enzyme and Microbial Technology 36, 318-326.

Todorov, S.D., Dicks L.M.T. 2006a. Effect of medium components onbacteriocin production by Lactobacillus plantarum strains ST23LD and ST341LD, isolated from spoiled olive brine. Research in Microbiology 161, 102-108.

Todorov, S.D., Dicks L.M.T. 2006b. Medium components effecting bacteriocin production by two strains of Lactobacillus plantarum ST414BZ and ST664BZ isolated from boza. Biologia 61, 269-274.

Todorov, S.D., Nyati, H., Meincken, M., Dicks, L.M.T. 2007a. Partialcharacterization of bacteriocin AMA-K, produced by Lactobacillus plantarum AMA-K isolated from naturally fermented milk from Zimbabwe. Food Control 18, 656-664.

Todorov, S.D., Powell, J.E., Meincken, M., Witthuhn R.C., Dicks L.M.T. 2007b. Factors affecting the adsorption of Lactobacillus plantarum bacteriocin bacST8KF to Enterococcus faecalis and Listeria innocua. International Journal of Dairy Technology 60, 221-227.

Todorov, S.D. 2008. Bacteriocin production by Lactobacillus plantarum AMA-K isolated from Amasi, a Zimbabwean fermented milk product and study of adsorption of bacteriocin AMA-K to Listeria spp. Brazilian Journal of Microbiology 38, 178-187.

Turbic, A., Ahokas, J.T., Haskard, C.A. 2002. Selective in vitro binding of dietary mutagens, individually or in combination, by lactic acid bacteria. Food Additives $\mathcal{E}$ Contaminants 19, 144-152.

Thyagaraja, N., Hosono, A. 1994. Binding properties of lactic acid bacteria from 'Idly' towards food-borne mutagens. Food and Chemical Toxicology 32, 805-809.

Zotta, T., Parente, E., Ricciardi, A. 2009. Viability staining and detection of metabolic activity of sourdough lactic acid bacteria under stress conditions. World Journal of Microbiology and Biotechnology 25 (6), 1119-1124.

Valerio, F. Favilla, M., De Bellis, P., Sisto, A., de Candia, S., Lavermicocca, P. 2009. Antifungal activity of strains of lactic acid bacteria isolated from a semolina ecosystem against Penicillium roqueforti, Aspergillus niger and Endomyces fibuliger contaminating bakery products. Systematic and Applied Microbiology 32 (6), 438-448.

Valerio, F., De Bellis, P., Lonigro, S.L., Visconti, A., Lavermicocca, P. 2008. Use of Lactobacillus plantarum fermentation products in bread-making to prevent Bacillus subtilis ropy spoilage. International Journal of Food Microbiology 122 (3), 328-332.

Varga, J., Kozakiewicz, Z. 2006. Ochratoxin-A in grapes and grape-derived products. Trends in Food Science \& Technology 1, 72-81. 
Verellen, T.L.J., Bruggeman, G., Van Reenen, C.A., Dicks, L.M.T., Vandamme, E.J. 1998. Fermentation optimization of plantaricin 423, a bacteriocin produced by Lactobacillus plantarum 423. Journal of Fermentation and Bioengineering 86, 174-179.

Verluyten, J., Leroy, F., De Vuyst, L. 2004a. Influence of complex nitrogen source on growth of and curvacin A production by sausage isolate Lactobacillus curvatus LTH1174. Applied and Environmental Microbiology 70, 5081-5088.

Viljoen, C.R., von Holy, A. 1997. Microbial populations associated with commercial bread production. Journal of Basic Microbiology 37 (6), 439-444.

Volavsek, P.J.A., Kirshner, L.A.M., von Holy, A. 1992. Accelerated methods to predict the rope-inducing potential of bread raw materials. South African Journal of Science 87, 99-102.

Wiedemann, I., Breukink, E., van Kraaij, C., Kuipers, O.P., Bierbaum, G., de Kruijff, B., Sahl, H.G. 2001. Specific binding of nisin to the peptidoglycan precursor lipid II combines pore formation and inhibition of cell wall biosynthesis for potent antibiotic activity. The Journal of Biological Chemistry 276 (3), 1772-1779.

Wiseman, D.W., Marth, E.H. 1981. Growth and aflatoxin production by Aspergillus parasiticus when in the presence of Streptococcus lactis, Mycopathologia 73, 49-56.

Worobo, R.W., Van Belkum, M.J., Sailer, M., Roy, K.L., Vederas, J.C., Stiles, M.E. 1995. A signal peptide secretion-dependent bacteriocin from Carnobacterium divergens. Journal of Bacteriology 177 (11), 3143-3149.

Quintavalla, S., Parolari, G. 1993. Effects of temperature, aw and $\mathrm{pH}$ on the growth of Bacillus cells and spores: a response surface methodology study. International Journal of Food Microbiology 19 (3), 207-216. 


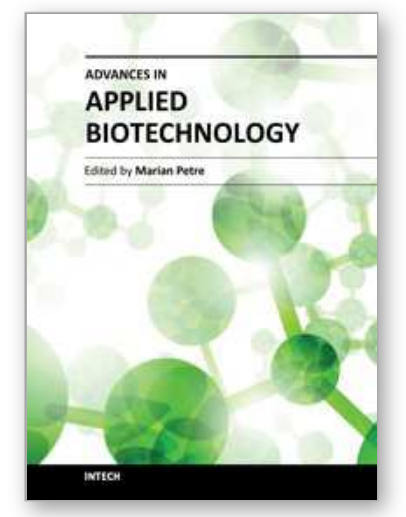

\author{
Advances in Applied Biotechnology \\ Edited by Prof. Marian Petre
}

ISBN 978-953-307-820-5

Hard cover, 288 pages

Publisher InTech

Published online 20, January, 2012

Published in print edition January, 2012

Biotechnology is the scientific field of studying and applying the most efficient methods and techniques to get useful end-products for the human society by using viable micro-organisms, cells, and tissues of plants or animals, or even certain functional components of their organisms, that are grown in fully controlled conditions to maximize their specific metabolism inside fully automatic bioreactors. It is very important to make the specific difference between biotechnology as a distinct science of getting valuable products from molecules, cells or tissues of viable organisms, and any other applications of bioprocesses that are based on using the whole living plants or animals in different fields of human activities such as bioremediation, environmental protection, organic agriculture, or industrial exploitation of natural resources. The volume Advances in Applied Biotechnology is a scientific book containing recent advances of selected research works that are ongoing in certain biotechnological applications. Fourteen chapters divided in four sections related to the newest biotechnological achievements in environmental protection, medicine and health care, biopharmaceutical producing, molecular genetics, and tissue engineering are presented.

\title{
How to reference
}

In order to correctly reference this scholarly work, feel free to copy and paste the following:

Grazina Juodeikiene, Elena Bartkiene, Pranas Viskelis, Dalia Urbonaviciene, Dalia Eidukonyte and Ceslovas Bobinas (2012). Fermentation Processes Using Lactic Acid Bacteria Producing Bacteriocins for Preservation and Improving Functional Properties of Food Products, Advances in Applied Biotechnology, Prof. Marian Petre (Ed.), ISBN: 978-953-307-820-5, InTech, Available from: http://www.intechopen.com/books/advances-inapplied-biotechnology/fermentation-processes-using-lactic-acid-bacteria-producing-bacteriocins-forpreservation-and-improv

\section{INTECH}

open science | open minds

\author{
InTech Europe \\ University Campus STeP Ri \\ Slavka Krautzeka 83/A \\ 51000 Rijeka, Croatia \\ Phone: +385 (51) 770447 \\ Fax: +385 (51) 686166 \\ www.intechopen.com
}

\author{
InTech China \\ Unit 405, Office Block, Hotel Equatorial Shanghai \\ No.65, Yan An Road (West), Shanghai, 200040, China \\ 中国上海市延安西路65号上海国际贵都大饭店办公楼 405 单元 \\ Phone: +86-21-62489820 \\ Fax: +86-21-62489821
}


(C) 2012 The Author(s). Licensee IntechOpen. This is an open access article distributed under the terms of the Creative Commons Attribution 3.0 License, which permits unrestricted use, distribution, and reproduction in any medium, provided the original work is properly cited. 